\title{
New shallow water species of Caribbean Ircinia Nardo, 1833 (Porifera: Irciniidae)
}

\author{
JOSEPH B. KELLY',2* \& ROBERT W. THACKER ${ }^{1,3}$ \\ ${ }^{1}$ Stony Brook University, Department of Ecology and Evolution, Stony Brook, NY, USA. \\ ${ }^{2}$ Limnological Institute University Konstanz, Aquatic Ecology and Evolution, Konstanz, Germany. \\ ${ }^{3}$ Smithsonian Tropical Research Institute, PO Box 0843-03092, Balboa, Republic of Panama. \\ झ" robert.thacker@stonybrook.edu; ○ https://orcid.org/0000-0002-9654-0073 \\ *Corresponding author." joseph.kelly@uni-konstanz.de; @i https://orcid.org/0000-0001-7025-8806
}

\begin{abstract}
Seven Ircinia morphospecies were collected from three sites in the Caribbean (Bocas del Toro, Panama; the Mesoamerican Barrier Reef, Belize; and the Florida Keys, United States of America). Previous research used an integrative taxonomic framework (genome-wide SNP sampling and microbiome profiling) to delimit species boundaries among these Ircinia. Here, we present morphological descriptions for these species, six of which are new to science (Ircinia lowi sp. nov., Ircinia bocatorensis sp. nov., Ircinia radix sp. nov., Ircinia laeviconulosa sp. nov., Ircinia vansoesti sp. nov., Ircinia ruetzleri sp. nov.) in addition to one species conferre (Ircinia cf. reteplana Topsent, 1923).
\end{abstract}

Key words: Integrative taxonomy, Porifera, benthos, sponges

\section{Introduction}

The genus Ircinia Nardo, 1833 is currently comprised of 88 recognized species, 14 of which are documented to occur off the Atlantic coast of the Americas (van Soest et al. 2021). Three of these species are common in coral reefs and seagrass beds in the Caribbean: I. campana Lamarck, 1814; I. strobilina Lamarck, 1816; and I. felix Duchassaing \& Michelotti, 1864 (Rützler et al. 2000, Diaz 2005). Caribbean Ircinia are often among the most abundant species in sponge communities (Rützler et al. 2000, Diaz 2005, Wulff 2013) and possess microbial communities that are involved in processes at the base of the food web such as photosynthesis (Wilkinson \& Cheshire 1990, Erwin \& Thacker 2007) and biogeochemical cycling (Archer et al. 2017). Alongside these three species can be found several Ircinia growth forms that are recognizable in the field based on the overall shape of their bodies, the height and spacing of their conules, and the position and size of their oscula (van Soest 1978, Wulff 1994, Rützler et al. 2000, Diaz 2005, Erwin \& Thacker 2007, Wulff 2013). The growth forms are also regarded as being ecologically distinct in that they contain different tissue densities of chlorophyll $a$ (Erwin \& Thacker 2007), can exhibit habitat preference, and have distinct microbiome compositions (Kelly et al. 2021). Despite the ecological importance of Ircinia in the Caribbean and the longstanding recognition of these growth forms as putative species, a new species of Caribbean Ircinia has not been described in over forty years, with the last being I. hummelincki van Soest, 1978. Given their importance to ecological processes and the biodiversity that they impart to Caribbean benthos, the clarification of their taxonomy is of utmost importance.

The study of Ircinia taxonomy has been historically problematic as the genus, like other members of the order Dictyoceratida Minchin, 1900, does not produce endogenous spicules and presents few anatomical features that can be used to infer relatedness and taxonomic boundaries among species (Erpenbeck et al. 2020). Ircinia species also display a considerable degree of intraspecific morphological plasticity that confounds the identification of features that are representative of a given species (Cook \& Bergquist 1999). Single-locus genetic barcoding has likewise seen limited success, as the loci that are typically used to provide species- and population-level phylogenetic resolution in metazoans, which include the cytochrome oxidase c subunit $1(\mathrm{CO} 1)$ and the internal transcribed 
spacer set (ITS), can be either incompletely sorted or largely invariant among nominal species of Ircinia (Kelly \& Thacker 2020 in review). The pitfalls that arise from the use of morphological data alone or by restricting genetic data to a single locus or a few loci, which is also a practice best avoided due to the high probability of gene tree and species tree discordance (Degnan \& Rosenberg 2006), necessitate the implementation of integrative taxonomic research frameworks within Ircinia that include genome-wide evidence of species boundaries. Recently, genetic species boundaries were delimited among several of these growth forms using Bayesian species delimitation with genome-wide SNP data (BFD*) (Leaché et al. 2014, Kelly et al. 2021). On the basis that these growth forms are genetically and morphologically distinct and are likely ecologically divergent as evidenced by their possession of unique microbiomes (Kelly et al. 2021), we designate the morphospecies as new species to science and provide taxonomic descriptions.

\section{Methods}
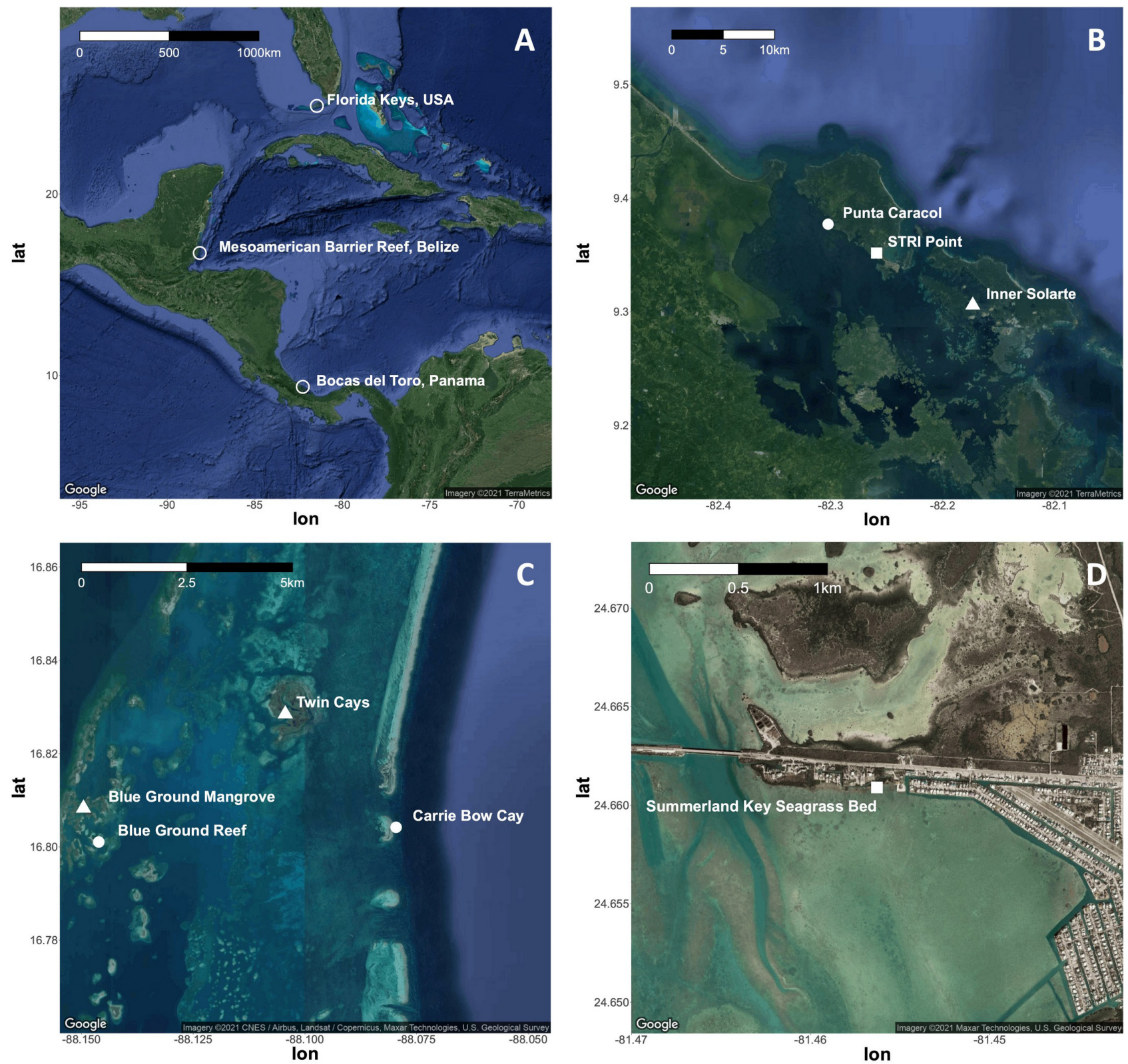

FIGURE 1. Maps of sampling locations. A: Overview of three sites; B: Bocas del Toro, Panama; C: Mesoamerican Barrier Reef, Belize; D: Summerland Key, United States of America. Open circles in A denote the location of field sites. In B-D, filled circles are coral reefs or coral patch reefs, squares are seagrass beds, and triangles are mangroves. 


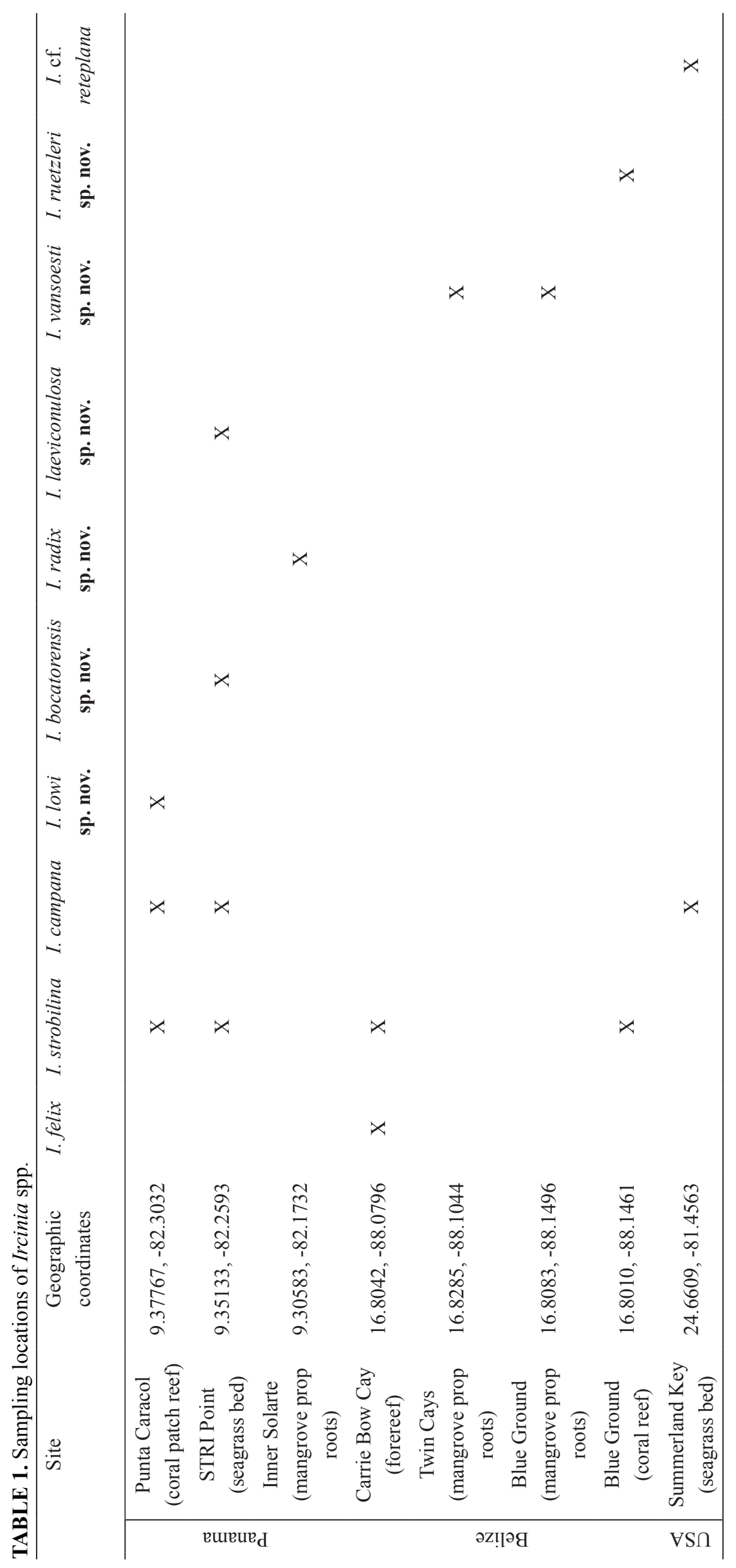


Ircinia spp. specimens were collected from three sites in the Caribbean: four morphospecies were collected from Bocas del Toro, Panama; two from the Mesoamerican Barrier Reef, Belize; and one from the Florida Keys, United States of America (Figure 1, Table 1). Immediately after collection and prior to fixation, measurements of oscula diameters were made using a dissecting microscope and measurements of conule heights were made under compound light microscopy using hand-cut sections.

Tissue samples were fixed in 4\% paraformaldehyde (PFA) that was prepared by diluting $32 \%$ PFA stock in filtered seawater. The 4\% PFA solution was replaced at the 24- and 48-hour marks to ensure complete irrigation of the tissue. 50 and 75 micron-thick histological sections were made of fixed tissue samples embedded in paraffin. Measurements of skeletal fiber widths and observations of fiber coring were then made using compound light microscopy. Fibers were measured at the midpoint between their connections to other fibers since they thicken as they approach the intersection.

\section{Results}

Among the 34 of the specimens collected at the sites indicated were three currently recognized species and seven additional morphospecies (Figure 1, Table 1). The species are distinguished morphologically based on their bodies' growth shapes, oscula sizes and positions, conule heights, fiber widths, and coring. Only one species, I. vansoesti, was found in more than one site visited. Below we produce taxonomic descriptions that allow the distinction of the morphospecies encountered.

\section{Systematics}

\section{Phylum Porifera Grant, 1836}

\section{Class Demospongiae Sollas, 1885}

\section{Subclass Keratosa Grant, 1861}

Order Dictyoceratida Minchin, 1900

\section{Family Irciniidae Gray, 1867}

\section{Genus Ircinia Nardo, 1833}

Diagnosis. The proteinaceous skeleton of irciniids is composed of primary fibers that are meshed together in fascicles. A system of secondary fibers intersect, often perpendicularly, with the fascicles and can differ in the degree of coring and fiber widths relative to the primary fibers. The networks of interconnecting secondary and fascicular primary fibers are reinforced by nearly transparent, thin fibers (termed irciniid filaments) that can be tightly packed in pleatlike layers or arranged in tracts, making the bodies of many irciniids compressible though difficult to tear. Ircinia are distinguishable from Psammocinia Lendenfeld, 1889 by the former's absence of a thick outer layer of sediment that forms a cortical armor. The dermis of Ircinia is conulated and often clear of epibiont growth. Ircinia display a wide range of intraspecific variation in morphological characters at the macro- and microscopic level. Modified from Hooper \& van Soest (2002); see Discussion for remarks on secondary fiber coring.

Ircinia lowi sp. nov.

Figures 2, 3; Tables 1, 2.

urn:Isid:zoobank.org:act:78177724-A5A5-4396-B78D-F6A8181ACB82

Holotype: USNM 1582268 (P16x42; 9.37767, -82.3032; appx. 0.5 m depth; coll. J.B.K.; 22 July 2016). 
Paratypes: USNM 1582267 (P16x41; 9.37767, -82.3032; appx. $0.5 \mathrm{~m}$ depth; coll. J.B.K.; 22 July 2016), USNM 1582269 (P16x43; 9.37767, -82.3032; appx. 0.5 m depth; coll. J.B.K.; 22 July 2016), USNM 1582270 (P16x44; 9.37767, -82.3032; appx. 0.5 m depth; coll. J.B.K.; 22 July 2016), USNM 1582278 (P16x52; 9.37767, -82.3032; appx. $0.4 \mathrm{~m}$ depth; coll. J.B.K.; 23 July 2016).

Type locality: Bocas del Toro, Panama.
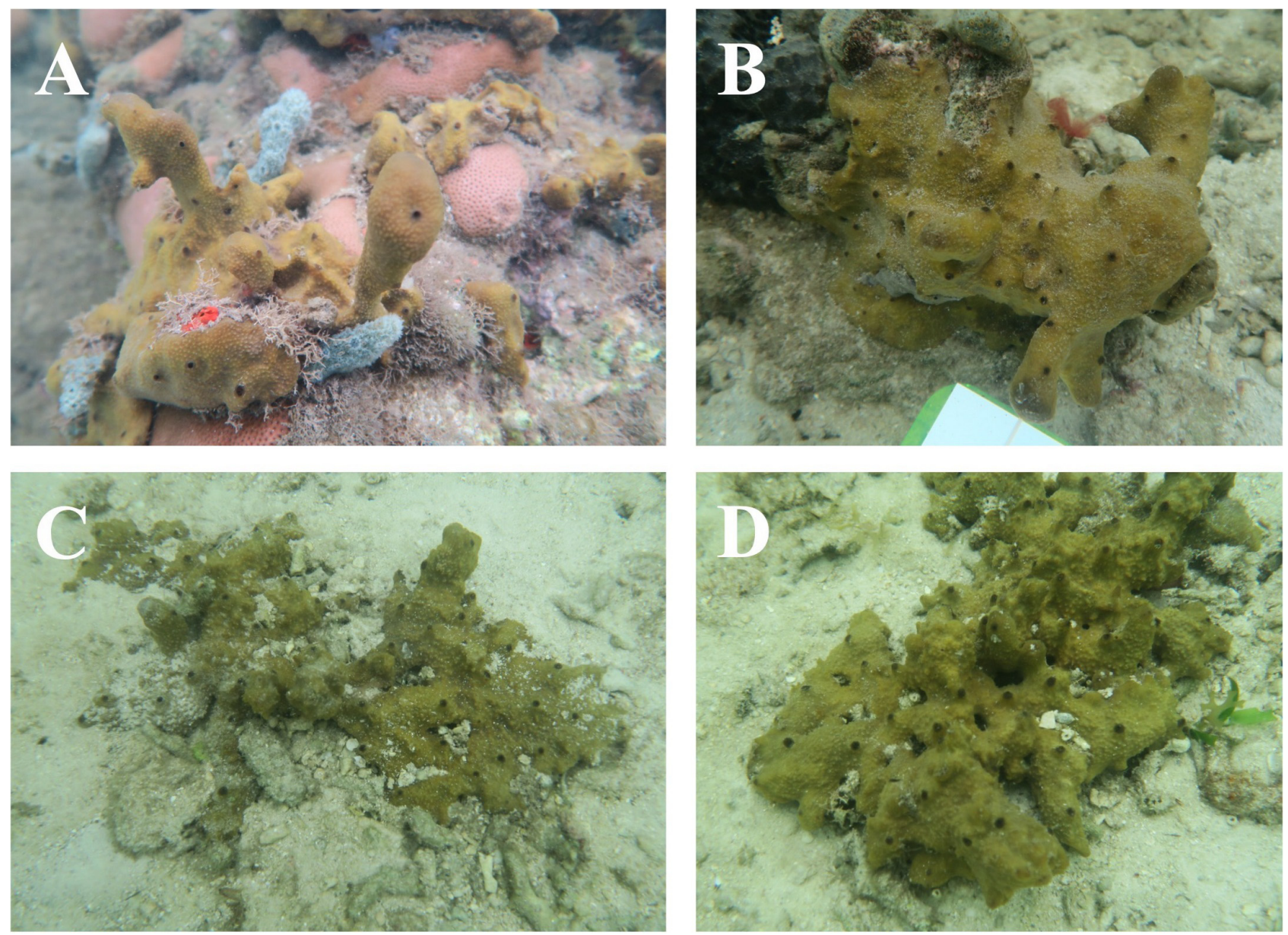

FIGURE 2. Ircinia lowi sp. nov. A: USNM 1582268 (holotype), B: USNM 1582267 (paratype), C: USNM 1582269 (paratype), D: USNM 1582270 (paratype). Note the wide points of attachment to hard substrate and coral rubble.

External morphology. Ircinia with a thickly encrusting growth habit and a forest green external surface color. Sometimes possesses lobate, short branches departing from base (Figure 2). Conules small (1.5-2 $\mathrm{mm}$ in height), sometimes of lighter color than the rest of the body. The body is dotted with black oscula that are uniform in size (0.4-0.5 cm diameter) and are either slightly elevated or flushed to the surface.

Interior morphology. Primary fascicular fibers 80-200 $\mu \mathrm{m}$ wide, cored. Interconnecting fibers 20-60 um wide, nearly uncored to completely uncored (Figure 3). Irciniid filaments $1-4 \mu \mathrm{m}$ wide, terminating in spherical knobs $6-10 \mu \mathrm{m}$ in diameter.

Ecology. All specimens were collected from shallow depths $(0.4-0.5 \mathrm{~m})$ on patch reefs that occur in association with small seagrass beds.

Etymology. This species is named for the immunologist Jun Siong Low for his methodological advances in identifying pan-coronavirus antibodies.

Remarks. Tissue takes on a slightly crisper consistency when preserved in ethanol for several days. Referred to as the 'Encrusting' growth form in Kelly et al. (2021). 

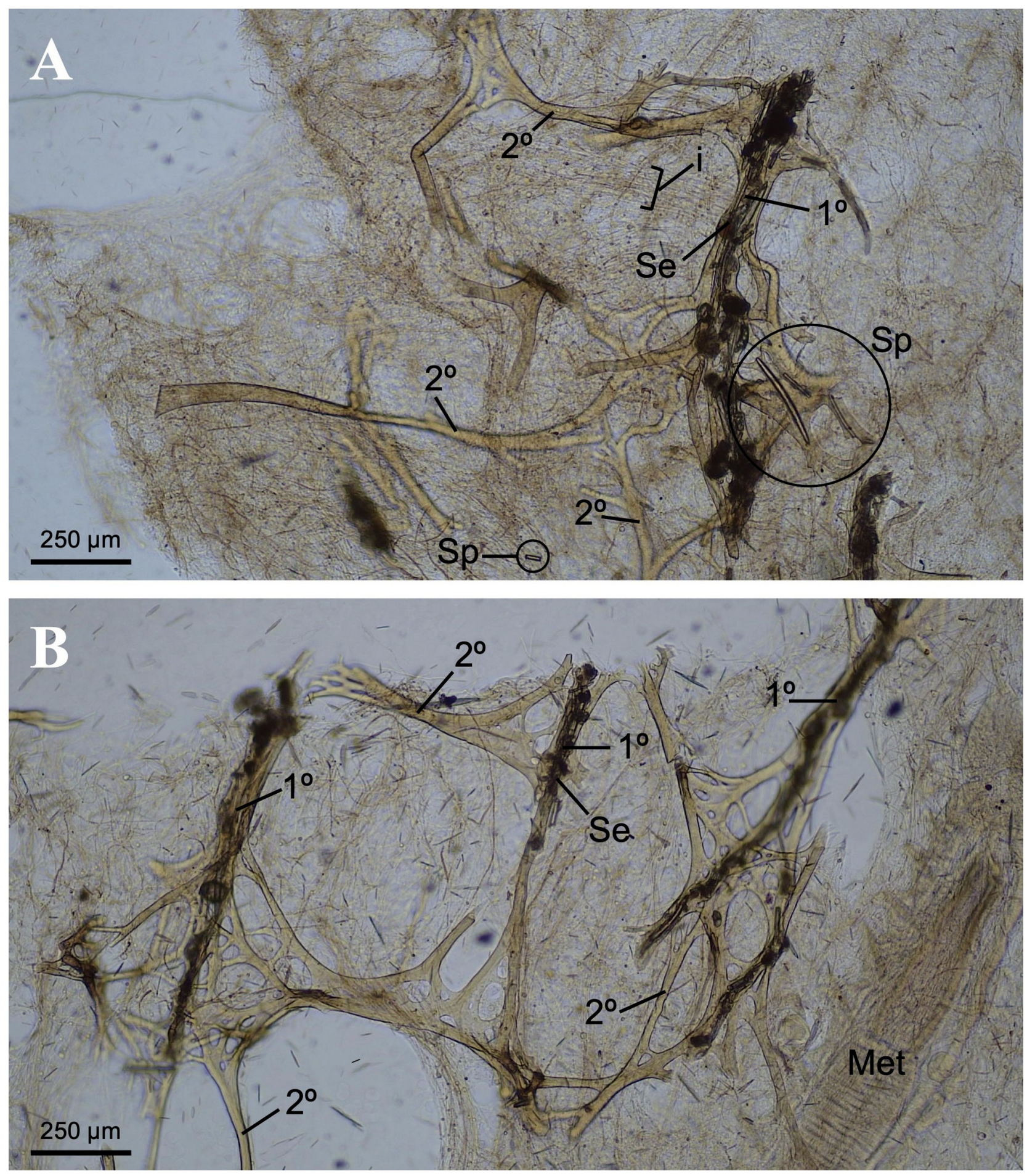

FIGURE 3. Histological sections of Ircinia lowi sp. nov., specimen voucher USNM 1582268 (holotype). Abbreviations: $1^{\circ}$ : primary fibers, $2^{\circ}$ : fibers, Sp: spicules, Se: sediment grains, Met: symbiotic metazoan, i: irciniid filaments. A: Bands of parallel irciniid filaments are visible throughout the mesohyl, with one plane of bands annotated by the bracket in the upper right-hand quadrant. Large, foreign spicule fragments are highlighted in the bottom right quadrant and at center bottom-left. B: Three primary fibers are joined by secondary fibers. Note the sand grains and spicule fragments in the primary fibers and their near absence from secondary fibers. 
Ircinia bocatorensis sp. nov.

Figures 4, 5; Tables 1, 2 .

urn:1sid:zoobank.org:act:D3F0FC15-2302-453D-BBAB-B3528E4D8D0A

Holotype: USNM 1582284 (P16x58; 9.35133, -82.2593; appx. 5 m depth; coll. J.B.K. and R.W.T.; 26 July 2016).

Paratypes: USNM 1582282 (P16x56; 9.35133, -82.2593; appx. 5 m depth; coll. J.B.K. and R.W.T.; 26 July 2016), USNM 1582287 (P16x61; 9.35133, -82.2593; appx. $5 \mathrm{~m}$ depth; coll. J.B.K. and R.W.T.; 26 July 2016), USNM 1582289 (P16x63; 9.35133, -82.2593; appx. $5 \mathrm{~m}$ depth; coll. J.B.K. and R.W.T.; 26 July 2016), USNM 1582291 (P16x65; 9.35133, -82.2593; appx. 5 m depth; coll. J.B.K. and R.W.T.; 26 July 2016), USNM 1582295 (P16x69; 9.35133, -82.2593; appx. 5 m depth; coll. J.B.K. and R.W.T.; 26 July 2016).

Type locality: Bocas del Toro, Panama.
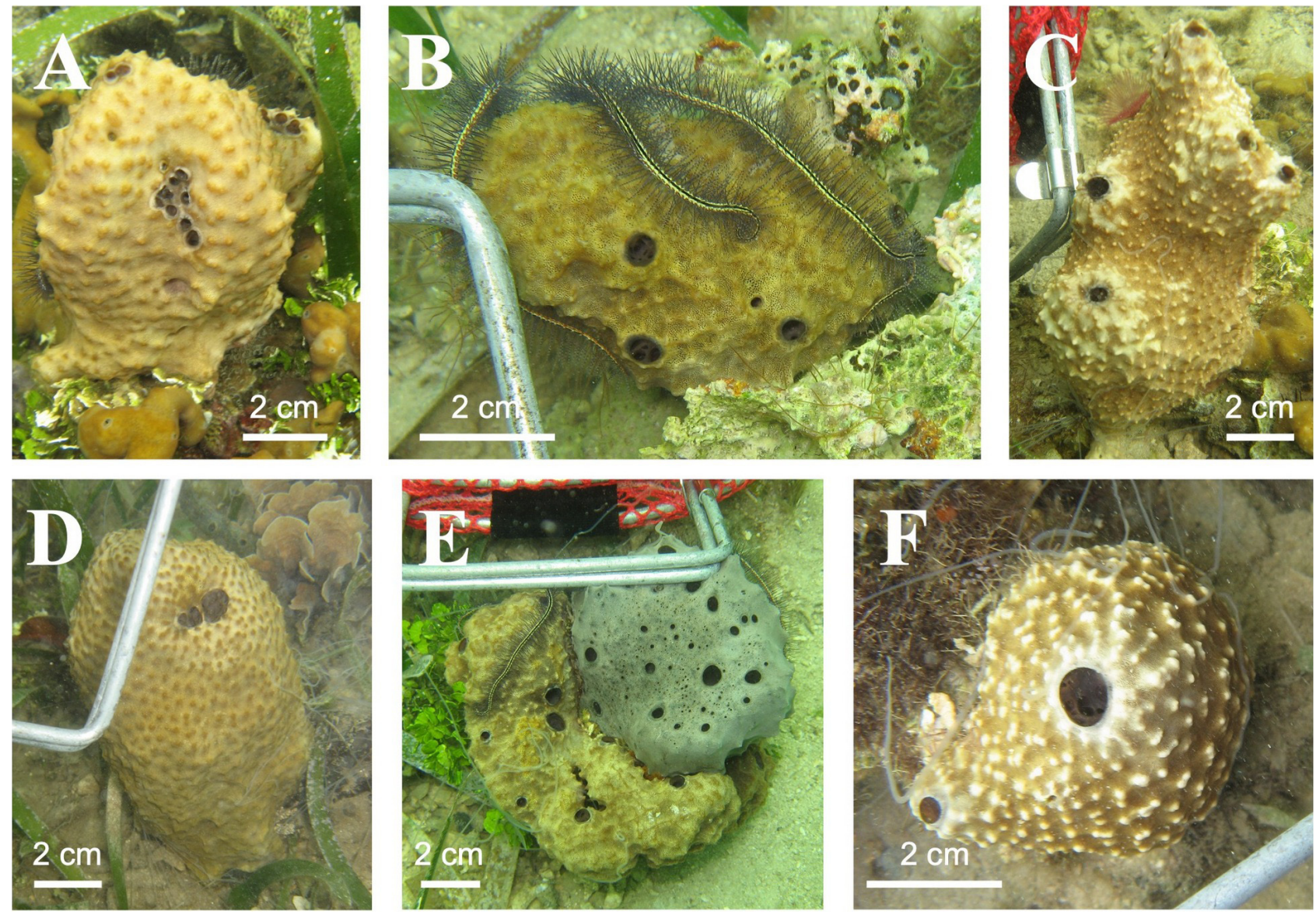

FIGURE 4. Ircinia bocatorensis sp. nov. A: USNM 1582284 (holotype), B: USNM 1582289 (paratype) with ophiuroid, C: USNM 1582287 (paratype), D: USNM 1582295 (paratype), E: USNM 1582291 (paratype, brownish) adjacent to I. strobilina (grayish), F: USNM 1582282 (paratype).

Exterior morphology. Ircinia with a massive, sometimes cone-like growth morphology and a tan exterior color (Figure 4). Conules 3-5 mm in height, dully sharp to knobby, typically darker or lighter in color than the rest of the sponge body. Oscula usually black, either flush or apical on cone-like outgrowths, sparsely distributed, sometimes clumped. Oscule diameter $0.5-1.5 \mathrm{~cm}$.

Internal morphology. Primary fascicular fibers $200-520 \mu \mathrm{m}$ wide, heavily cored. Interconnecting fibers 15-65 $\mu \mathrm{m}$ wide, moderately cored and sometimes becoming uncored further from the point of connection with the primary fibers (Figure 5). Irciniid filaments $1-4 \mu \mathrm{m}$ wide, terminating in spherical to oval knobs 5-10 $\mu \mathrm{m}$ in diameter.

Ecology. All specimens were collected from a Thalassia bed interspersed with small coral colonies.

Etymology. The species is named for the Panamanian province Bocas del Toro.

Remarks. One specimen was observed growing in physical contact with I. strobilina. Referred to as the 'Massive B' growth form in Kelly et al. (2021). 

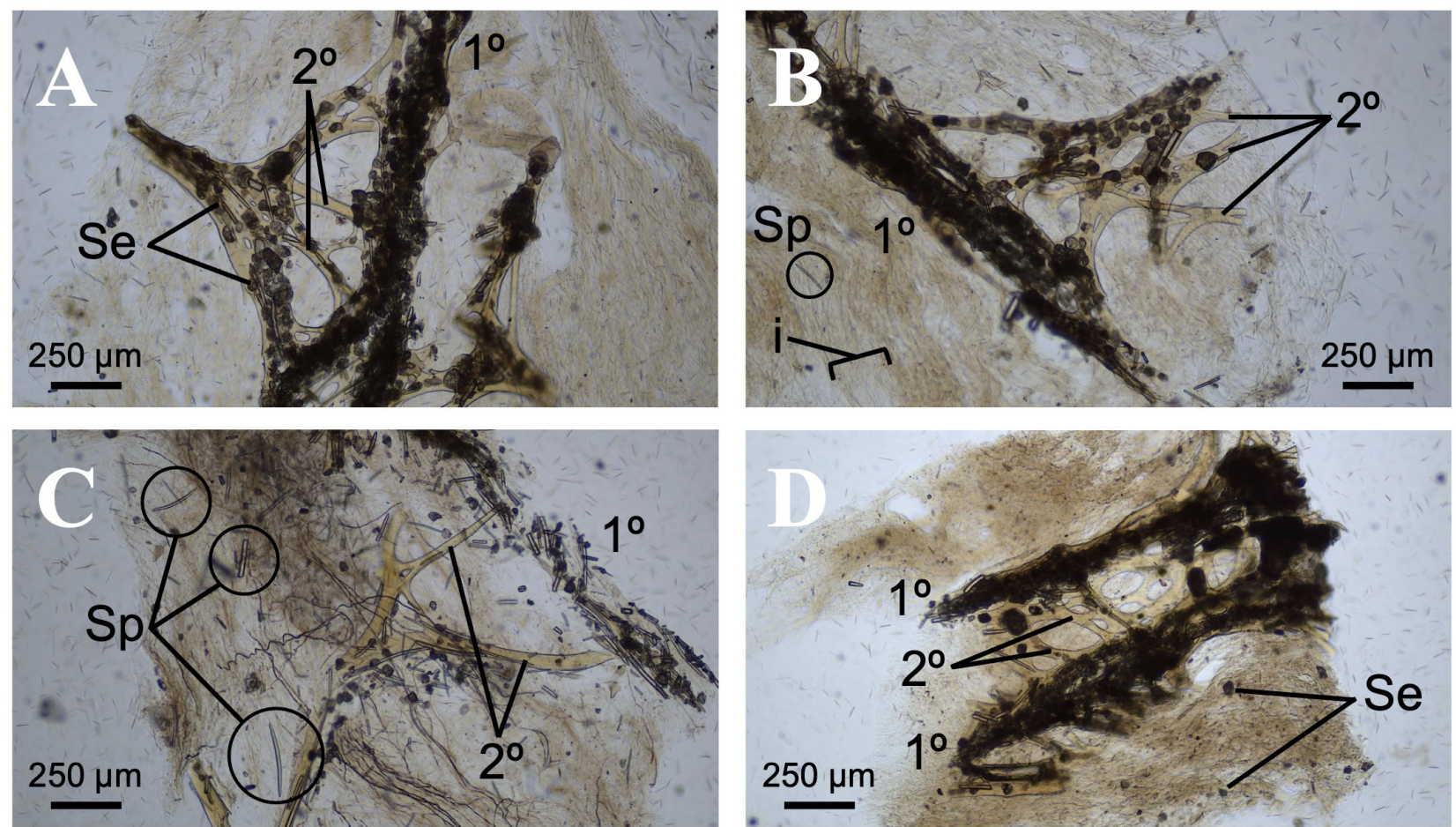

FIGURE 5. Histological sections of Ircinia bocatorensis sp. nov. Abbreviations follow Figure 3. A, B: USNM 1582284 (holotype). The holotype was chosen in part due to the success of the histology in demonstrating the variability in the degree of coring observed in the secondary fibers within a given individual of this species. A representative band of parallel irciniid filaments is annotated by the bracket in B. C: USNM 1582289 (paratype). Note the sparse coring of the secondary fibers. D: USNM 1582282 (paratype). This tissue fragment shows the often-parallel orientation of the primary fibers.

Ircinia radix sp. nov.

Figures 6, 7; Tables 1, 2.

urn:Isid:zoobank.org:act:5E1E2B6C-0345-4449-B185-5E27D58DE4E2

Holotype: USNM 1582258 (P16x32; 9.30583, -82.1732; appx. $0.5 \mathrm{~m}$ depth; coll. J.B.K. and R.W.T.; 21 July 2016).

Paratypes: USNM 1582257 (P16x31; 9.30583, -82.1732; appx. $0.5 \mathrm{~m}$ depth; coll. J.B.K. and R.W.T.; 21 July 2016), USNM 1582259 (P16x33; 9.30583, -82.1732; appx. $0.5 \mathrm{~m}$ depth; coll. J.B.K. and R.W.T.; 21 July 2016), USNM 1582260 (P16x34; 9.30583, -82.1732; appx. $0.5 \mathrm{~m}$ depth; coll. J.B.K. and R.W.T.; 21 July 2016).

Type locality: Bocas del Toro, Panama.

External morphology. Ircinia with a massive growth form and light to bright pink pinacoderm (Figure 6). Growth morphology can range from a round ball (Figure 6A-C) to massive form with variously shaped upright elongations (Figure 6D). Surface with low, rounded conules $(1.5-2 \mathrm{~mm}$ ). Oscula, $0.2-1.2 \mathrm{~cm}$ in diameter, flushed to the surface or slightly recessed, with a lighter-colored oscular membrane, usually white. Secondary smaller apertures may be sparsely distributed, made by animals inhabiting the sponge interior.

Interior morphology. Fascicular fibers $110-250 \mu \mathrm{m}$ wide, heavily cored. Interconnecting fibers 10-50 um wide, lightly cored with elongate foreign spicules oriented in parallel to the axis of the fiber and occasional sediment grains (Figure 7). Irciniid filaments $1-4 \mu \mathrm{m}$ wide, terminating in knobs with highly variable shapes, ranging from spherical to oval to tear-drop, and measuring $4-12 \mu \mathrm{m}$ in diameter.

Ecology. This species inhabits shaded entanglements of mangrove roots.

Etymology. The name refers to the mangrove roots that this species lives on.

Remarks. Referred to as the 'Massive A pink' growth form in Kelly et al. (2021). 

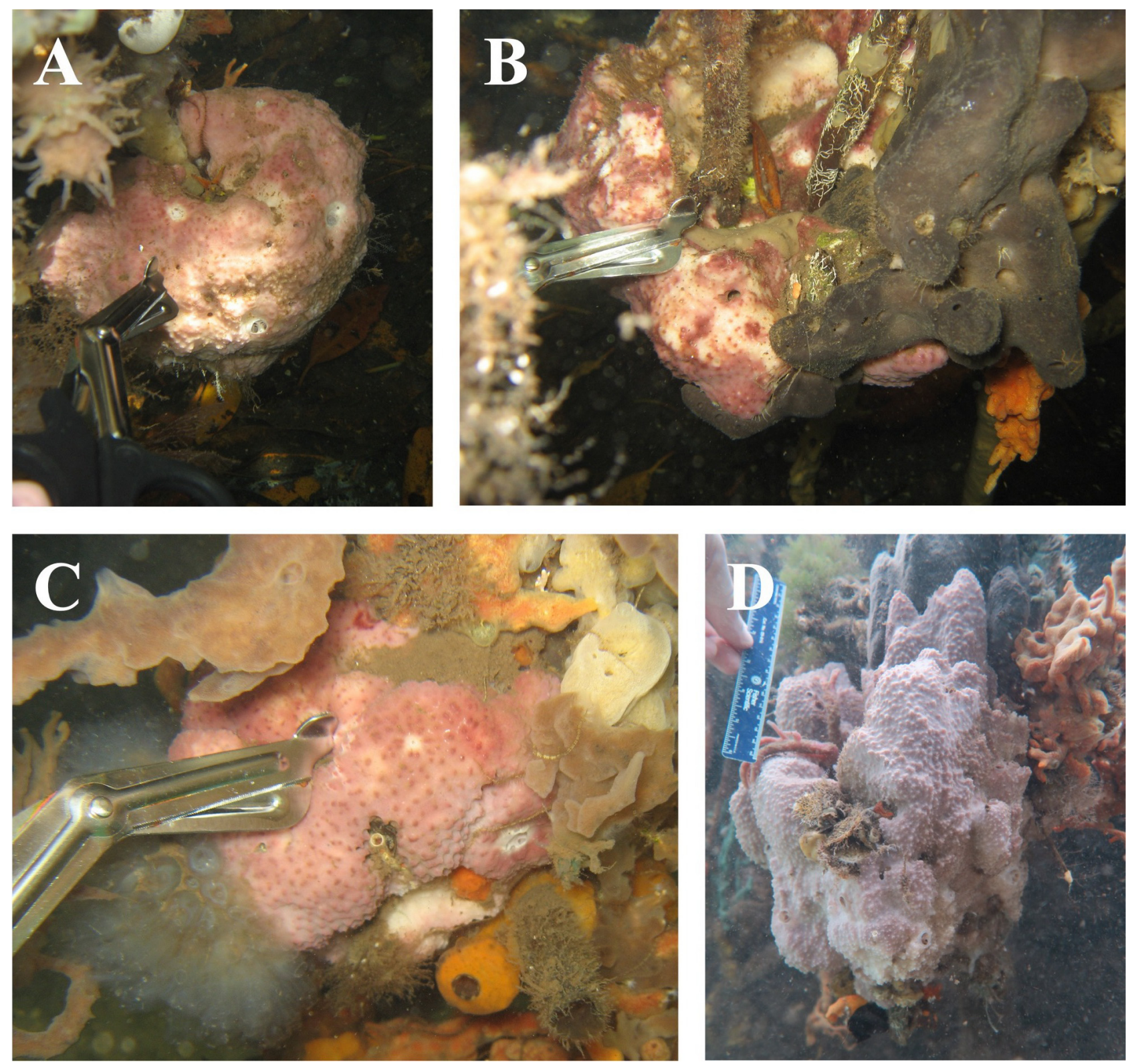

FIGURE 6. Ircinia radix sp. nov. A: USNM 1582258 (holotype), B: USNM 1582259 (paratype), C: USNM 1582260 (paratype), D: USNM 1582257 (paratype). All specimens were found growing on Rhizophora prop roots in shaded spots. 

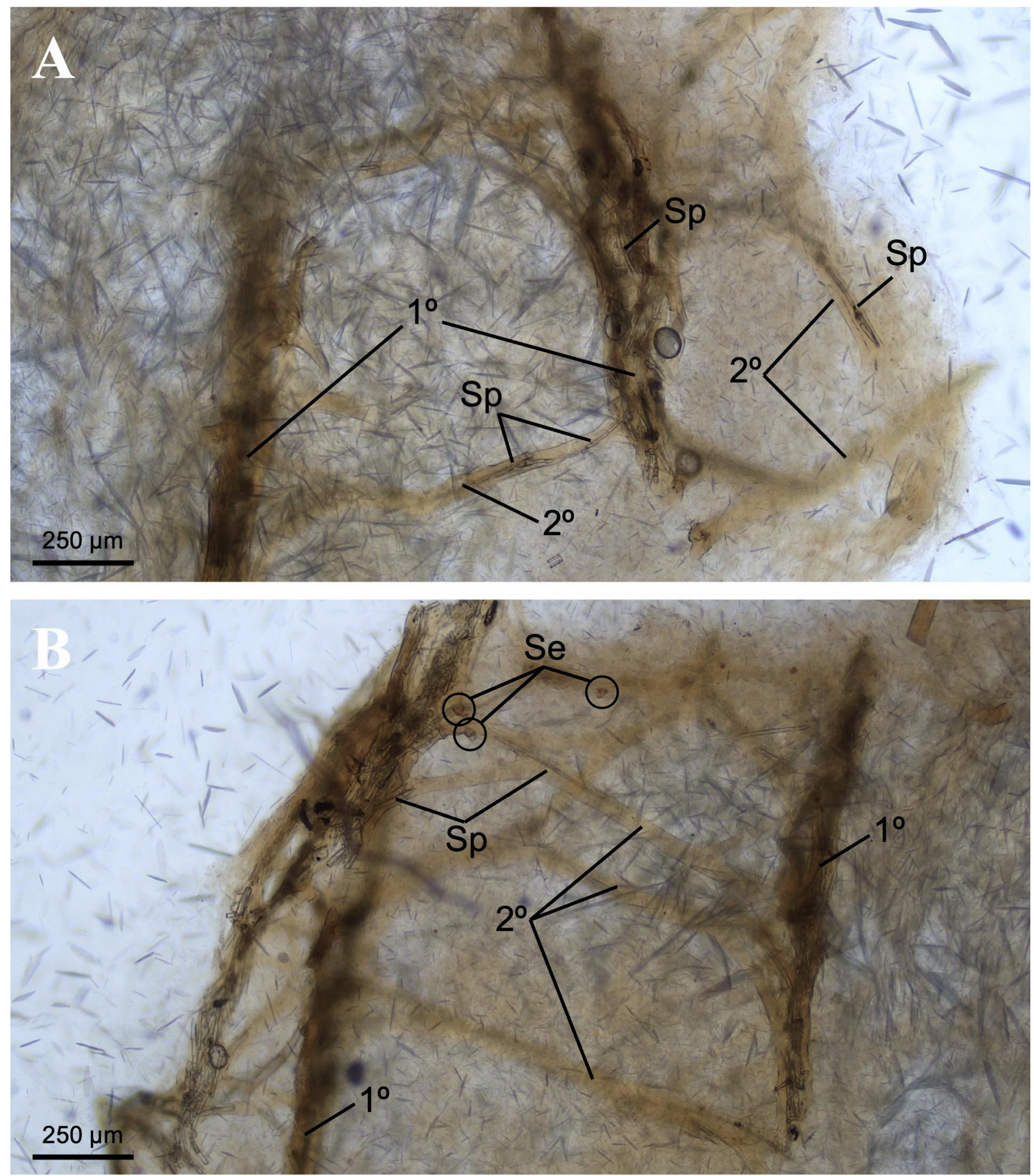

FIGURE 7. A, B: Histological sections of Ircinia radix sp. nov., specimen voucher USNM 1582258 (holotype). Abbreviations follow Figure 3.

Ircinia laeviconulosa sp. nov.

Figures 8, 9; Tables 1, 2.

urn:lsid:zoobank.org:act:2F579603-36E6-4D5A-9009-FBB43A99247C

Holotype: USNM 1582283 (P16x57; 9.35133, -82.2593; appx. 5 m depth; coll. J.B.K. and R.W.T.; 26 July 2016). Paratypes: USNM 1582285 (P16x59; 9.35133, -82.2593; appx. 5 m depth; coll. J.B.K. and R.W.T.; 26 July 
2016), USNM 1582286 (P16x60; 9.35133, -82.2593; appx. 5 m depth; coll. J.B.K. and R.W.T.; 26 July 2016), USNM 1582288 (P16x62; 9.35133, -82.2593; appx. 5 m depth; coll. J.B.K. and R.W.T.; 26 July 2016).

Type locality: Bocas del Toro, Panama.

External morphology. Ircinia with a massive growth form and dark green pinacoderm (Figure 8). Body diameter $10-15 \mathrm{~cm}$. Possesses low conules $(1.5-1.75 \mathrm{~mm})$. Oscula flush, sometimes slightly darker than the exterior of the sponge, $0.4-1.2 \mathrm{~cm}$ in diameter, and with a thin dark green or gray membrane.

Interior morphology. Massive fascicular fibers $110-160 \mu \mathrm{m}$ wide, heavily cored. Interconnecting fibers 20-50 um wide, sparsely cored (Figure 9). Irciniid filaments 1-5 $\mu \mathrm{m}$ wide, terminating in spherical to tear-drop knobs measuring $6-9 \mu \mathrm{m}$ in diameter.

Ecology. This species is found among Thalassia spp. and coral patches in shallow depths.

Etymology. The name refers to the texture imparted by the species' low conules.

Remarks. All specimens collected had a globose growth morphology. Referred to as the 'Massive A green' growth form in Kelly et al. (2021).
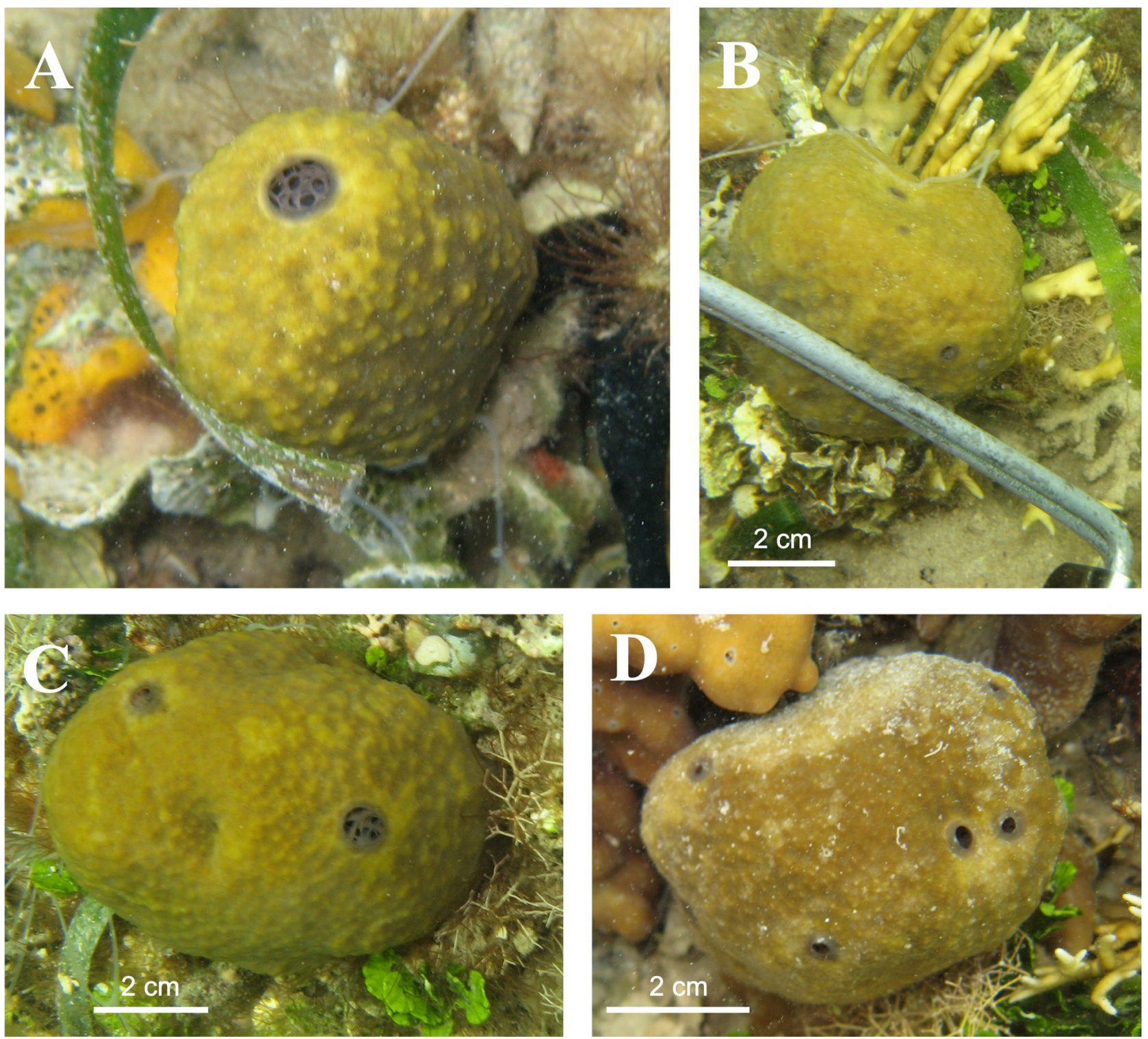

FIGURE 8. Ircinia laeviconulosa sp. nov. A: USNM 1582283 (holoype), B: USNM 1582285 (paratype), C: USNM 1582288 (paratype), D: USNM 1582286 (paratype). Note the variation in oscular position, from a single large osculum (A) to multiple smaller oscula (B-D). 

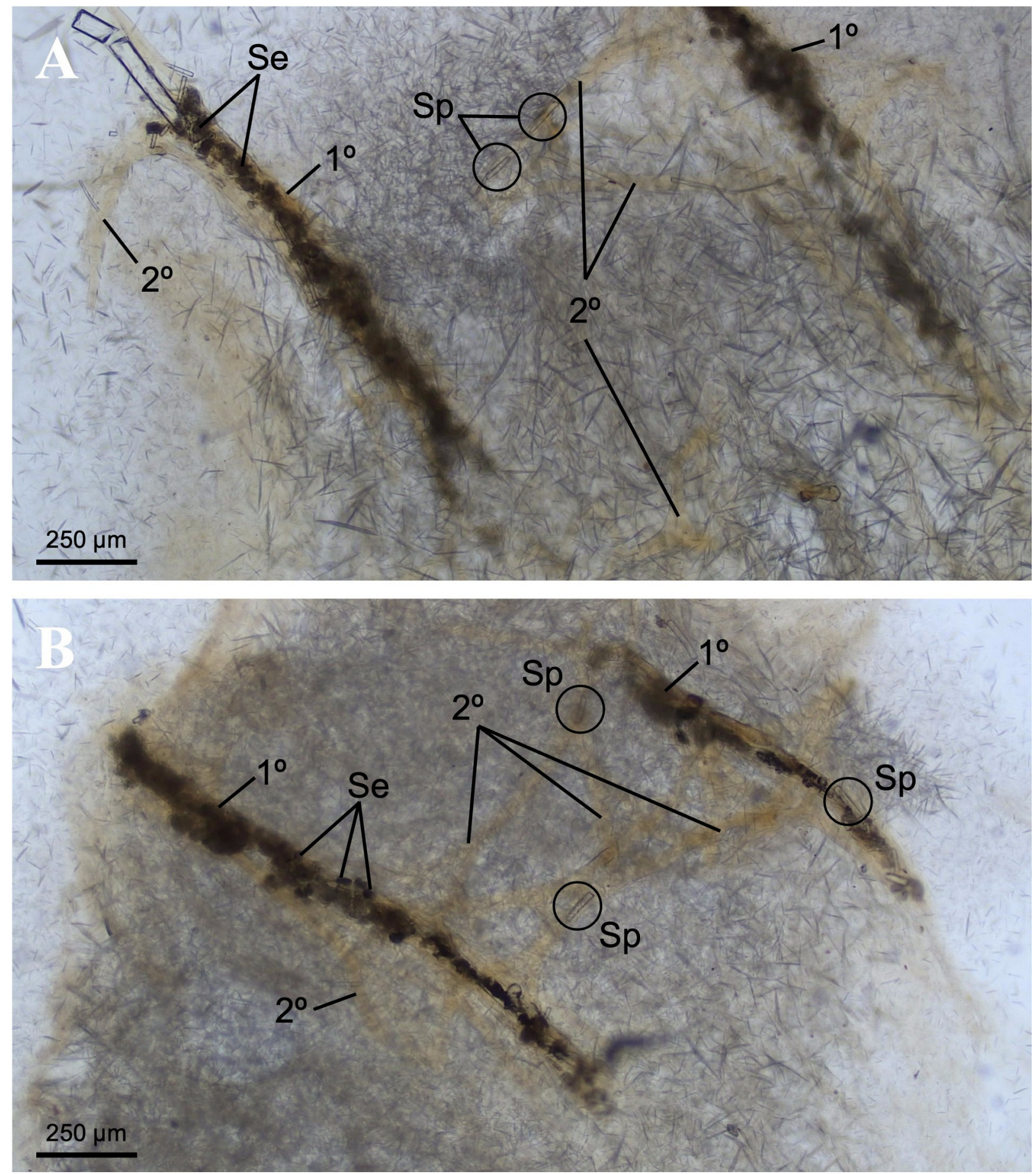

FIGURE 9. A,B: Histological sections of Ircinia laeviconulosa sp. nov., specimen voucher USNM 1582285 (paratype). Abbreviations follow Figure 3.

\section{Ircinia vansoesti sp. nov.}

Figures 10, 11; Tables 1, 2.

urn:Isid:zoobank.org:act:D3C1295B-95FC-4DDB-A3EF-35B0C2EAF3A8

Holotype: USNM 1641998 (JK18x20; 16.8285, -88.1044; appx. $0.6 \mathrm{~m}$ depth; coll. J.B.K.; 16 August 2018).

Paratypes: USNM 1641996 (JK18x18; 16.8285, -88.1044; appx. $0.6 \mathrm{~m}$ depth; coll. J.B.K.; 16 August 2018), USNM 1642006 (JK18x28; 16.8083, -88.1496; appx. 0.5 m depth; coll. J.B.K.; 18 August 2018), USNM 1642012 
(JK18x34; 16.8083, -88.1496; appx. 0.5 m depth; coll. J.B.K.; 18 August 2018), USNM 1642013 (JK18x35; 16.8083, -88.1496; appx. 0.5 m depth; coll. J.B.K.; 18 August 2018).

Type locality: Mesoamerican Barrier Reef, Belize.

External morphology. Ircinia with a ramose growth form, although can be occasionally massive lobate in smaller individuals (Figure 10). This species is polymorphic with regard to pinacoderm coloration, and multiple color morphs (gray, dark red, dark green) can be found within a population. Possesses smaller conules (1-1.5 mm). Oscula typically $0.5-1.2 \mathrm{~cm}$ in diameter.

Interior morphology. Massive fascicular fibers 90-300 $\mu \mathrm{m}$ wide, sometimes cored, and always more heavily than interconnecting fibers. Interconnecting fibers 25-60 um wide, usually uncored (Figure 11). Irciniid filaments 2-6 $\mu \mathrm{m}$ wide terminating in spherical to tear-drop knobs measuring 4-11 $\mu \mathrm{m}$ in diameter. Foreign spicules and sediment are occasionally included in the cortex and are seldom found in the in mesohyl. Fascicles can be rare and difficult to discern from interconnecting secondary fibers (Figure 11).

Ecology. This species is found growing on Rhizophora prop roots.

Etymology. This species is named for the sponge researcher Rob van Soest.

Remarks. Interior morphology can vary somewhat depending on population, as the Twin Cays specimens contained less foreign inclusions relative to the Blue Ground specimens. Referred to as the 'Sp. 1' growth form in Kelly et al. (2021).
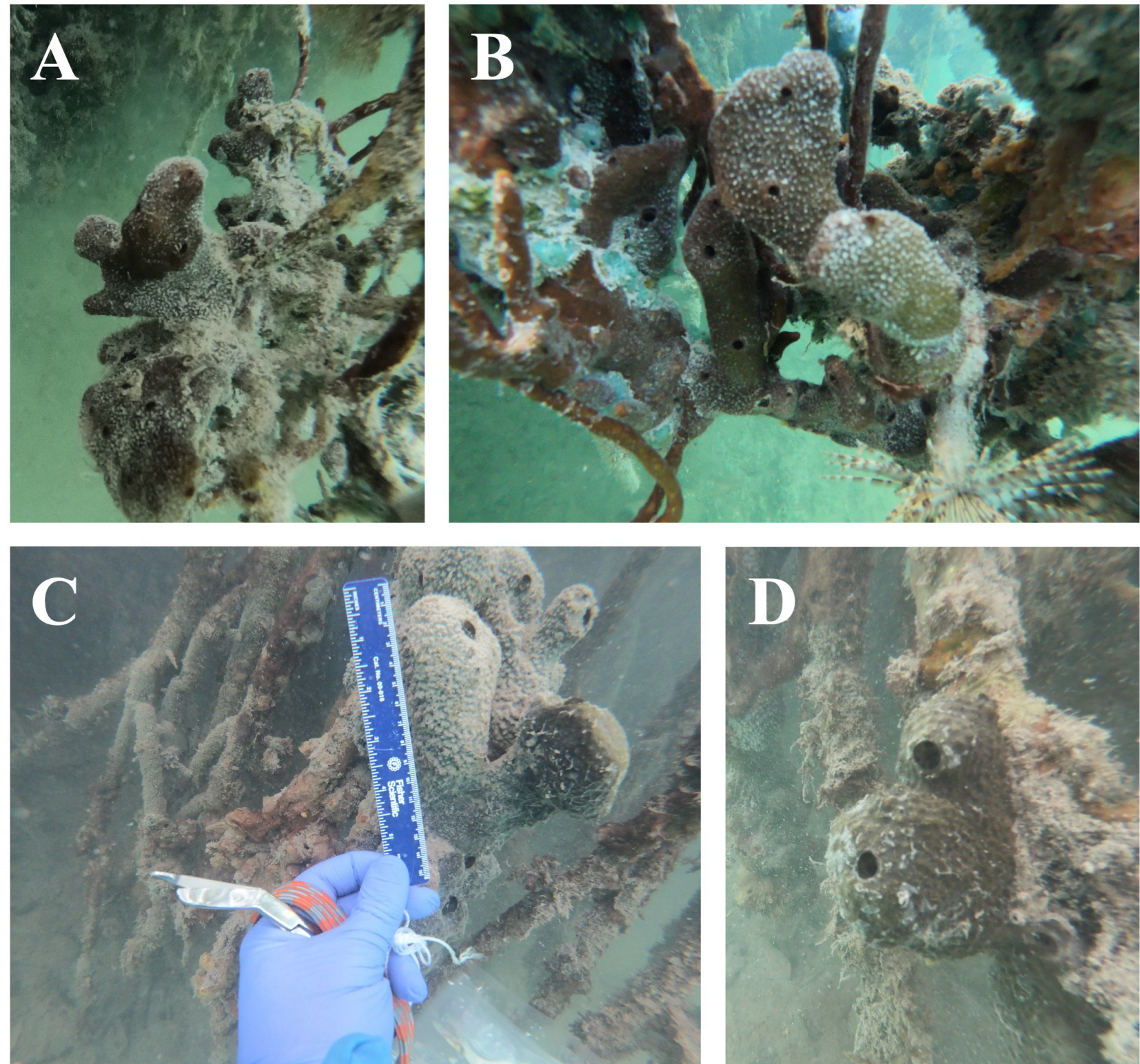

FIGURE 10. Ircinia vansoesti sp. nov. A: USNM 1641998 (holotype), B: USNM 1641996 (paratype), C: USNM 1642006 (paratype), D: USNM 1642013 (paratype). 

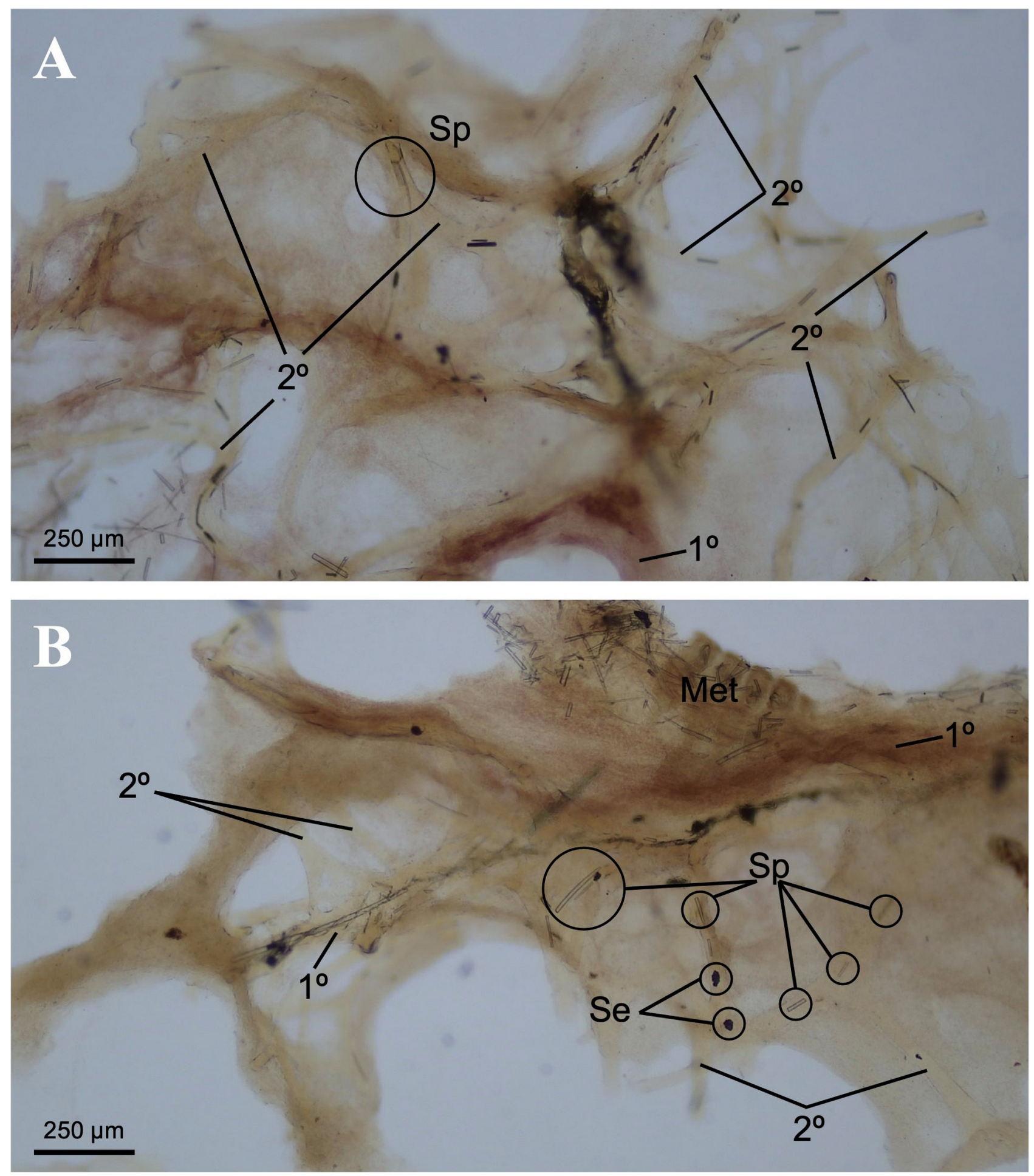

FIGURE 11. Histological sections of Ircinia vansoesti sp. nov. USNM 1641998 (holotype). Abbreviations follow Figure 3. A: Histological section demonstrating low degree of coring in secondary fibers. B: Section showing the higher degree of coring in primary fibers, most notably in the lower of the two primary fibers that runs horizontally across the image.

Ircinia ruetzleri sp. nov.

Figures 12, 13; Tables 1, 2.

urn:lsid:zoobank.org:act:C789E5F2-0BAB-4D78-9EFB-FD01E5E57D87

Holotype: USNM 1642001 (JK18x23; 16.8010, -88.1461; appx. $0.8 \mathrm{~m}$ depth; coll. J.B.K.; 17 August 2018). 
Paratypes: USNM 1641999 (JK18x21; 16.8010, -88.1461; appx. $0.8 \mathrm{~m}$ depth; coll. J.B.K.; 17 August 2018), USNM 1642000 (JK18x22; 16.8010, -88.1461; appx. 0.8 m depth; coll. J.B.K.; 17 August 2018), USNM 1642003 (JK18x25; 16.8010, -88.1461; appx. $0.8 \mathrm{~m}$ depth; coll. J.B.K.; 17 August 2018), USNM 1642004 (JK18x26; 16.8010, -88.1461; appx. $0.8 \mathrm{~m}$ depth; coll. J.B.K.; 17 August 2018).

Type locality: Mesoamerican Barrier Reef, Belize.

External morphology. Ircinia with an encrusting growth form, commonly with digitate projections, and dark gray pinacoderm (Figure 12). Conules $1-1.3 \mathrm{~mm}$ in height. Oscula flush or slightly raised, always black, $0.2-1 \mathrm{~cm}$ in diameter.

Interior morphology. Massive fascicular fibers 120-240 $\mu \mathrm{m}$ wide, heavily cored and tightly bound. Interconnecting fibers 30-50 um wide, lightly cored (Figure 13). Irciniid filaments $2-5 \mu \mathrm{m}$ wide, terminating in spherical knobs, 5-10 $\mu \mathrm{m}$ in diameter. Cortex contains abundant inclusions of sand grains.

Ecology. This species is found on patch reefs co-inhabited by I. strobilina in shallow depths $(0.5-1 \mathrm{~m})$ adjacent to mangrove hammocks inhabited by $I$. vansoesti sp. nov. The surface is often covered with loose sand. The species commonly grows in close association with hydroids and multicellular algae.

Etymology. This species is named in honor of the sponge researcher Klaus Rützler.

Remarks. Referred to as the 'Sp. 2' growth form in Kelly et al. (2021).
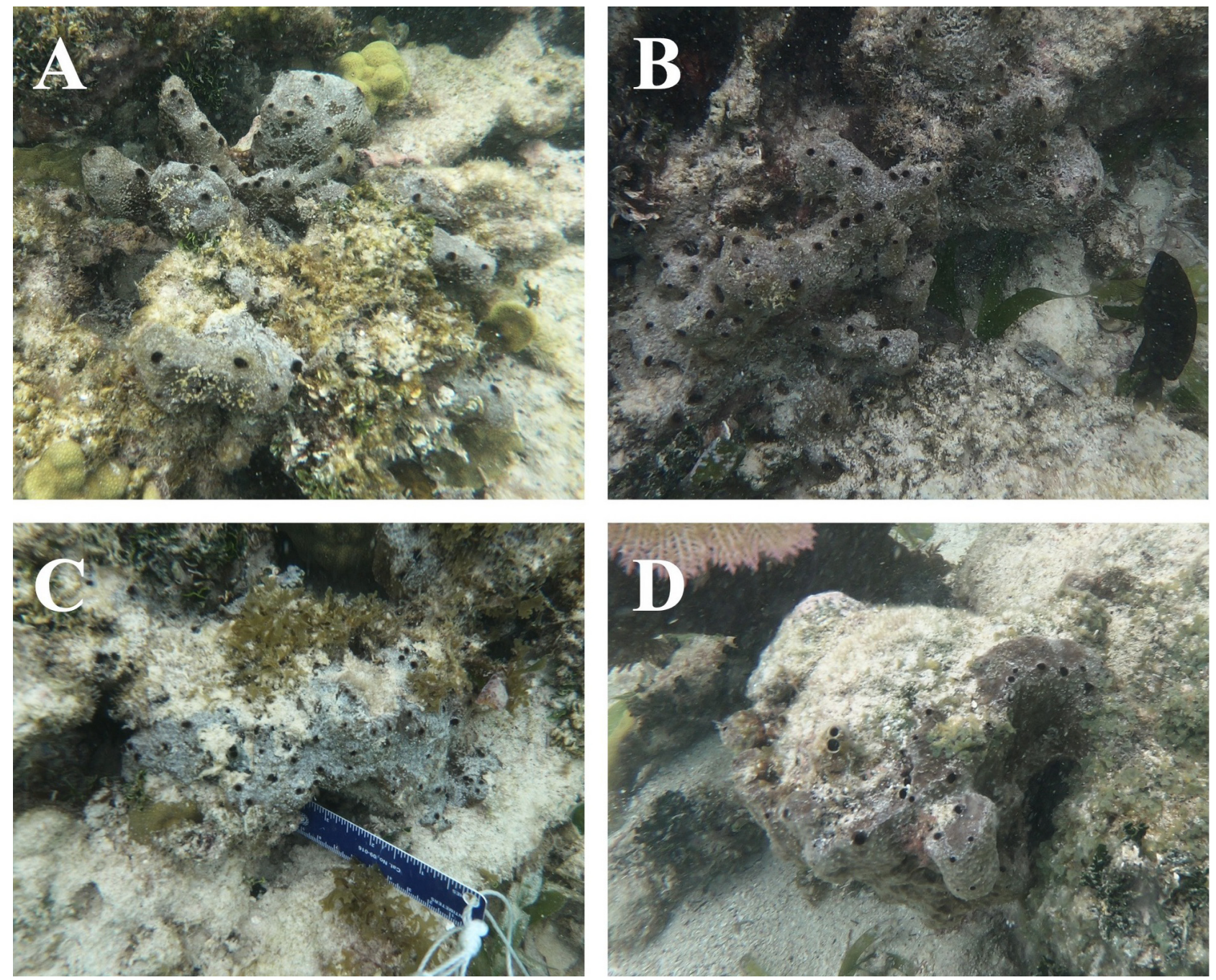

FIGURE 12. Ircinia ruetzleri sp. nov. A: USNM 1642001 (holotype), B: USNM 1642004 (paratype), C: USNM 1642000 (paratype), D: USNM 1642003 (paratype). 

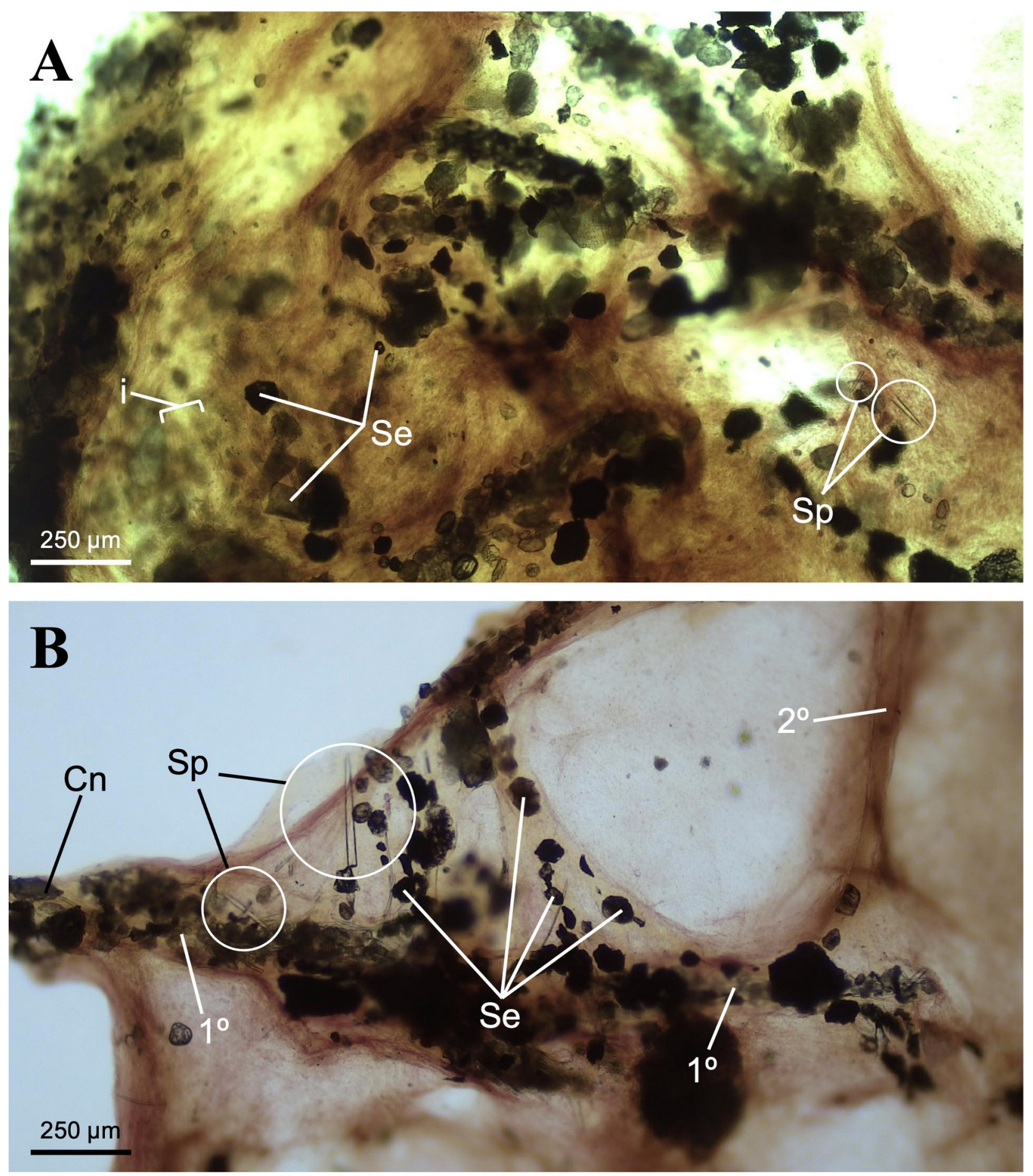

FIGURE 13. Histological sections of Ircinia ruetzleri sp. nov. USNM 1642001 (holotype). Abbreviations follow Figure 3. Cn denotes conule. A: Image showing sediment and spicules included in the mesohyl. A representative band of irciniid filaments is highlighted. B: Examples of sediment coring in a delta-like formation of secondary fibers. At the left of the image, a primary fiber terminates at the tip of a conule.

Ircinia cf. reteplana (Topsent, 1923)

Figures 14, 15; Tables 1, 2.

Representative specimens: USNM 1641981 (JK18x6; 24.6609, -81.4563; appx. $1.2 \mathrm{~m}$ depth; coll. J.B.K.; 5 July 2018), USNM 1641982 (JK18x7; 24.6609, -81.4563; appx. 1.2 m depth; coll. J.B.K.; 5 July 2018), USNM 1641984 
(JK18x9; 24.6609, -81.4563; appx. 1.2 m depth; coll. J.B.K.; 5 July 2018), USNM 1641985 (JK18x10; 24.6609, -81.4563; appx. $1.2 \mathrm{~m}$ depth; coll. J.B.K.; 5 July 2018), USNM 1641989 (JK18x14; 24.6609, -81.4563; appx. 1.2 m depth; coll. J.B.K.; 5 July 2018).

Collection locality: Summerland Key, Florida.

External morphology. Ircinia with a flattened, branching morphology. Branches are usually not interconnecting (Figure 14). Surface with 1-1.2 mm-high conules. Most oscula are around $0.5 \mathrm{~cm}$ in diameter and are found across the face of the branches, where they sit flush, as well as at the edges of the branches.

Interior morphology. Massive fascicular fibers are tightly bound, 90-250 $\mu \mathrm{m}$ wide, and heavily cored. Interconnecting fibers 20-80 um wide, moderately cored with spicules and sand (Figure 15). Irciniid filaments 2-6 $\mu \mathrm{m}$ wide, terminating in spherical knobs measuring $9-15 \mu \mathrm{m}$ in diameter. Cortex routinely incorporates sand and foreign spicule fragments.

Ecology. Specimens were collected from a Thalassia-dominated seagrass bed and co-occurred next to $I$. campana, sometimes within a meter of each other. Symbiotic metazoans in the sponge are mostly crustaceans and polychaetes.

Remarks. The body shape of I. reteplana Topsent, 1923 is distinct from those of the aforementioned Ircinia in that it is composed of flattened, interconnecting branches. Because the Floridian Ircinia growth form, called 'Ramose' in Kelly et al. (2021), often displays a flattened branching morphology, we designate this growth form as Ircinia cf. reteplana Topsent, 1923, and maintain it as conferre due to the moderate degree of coring observed in secondary fibers, a characteristic that is absent from I. reteplana Topsent, 1923. Additionally, the branches of I. cf. reteplana seldom interconnect, as is reported for I. reteplana Topsent, 1923, and can also possess a rounded branching morphology. This growth form represents either a new species of Ircinia or it represents an extension of the documented range of I. reteplana to the Florida Keys. For reference, the range of I. reteplana encompasses the entirety of the Antilles and spans the Caribbean to the coast of Venezuela, and extends to the tip of the Yucutan Peninsula (van Soest et al. 2021). The collections of I. strobilina, I. felix, and I. campana were made within the documented ranges of these species (Table 1).
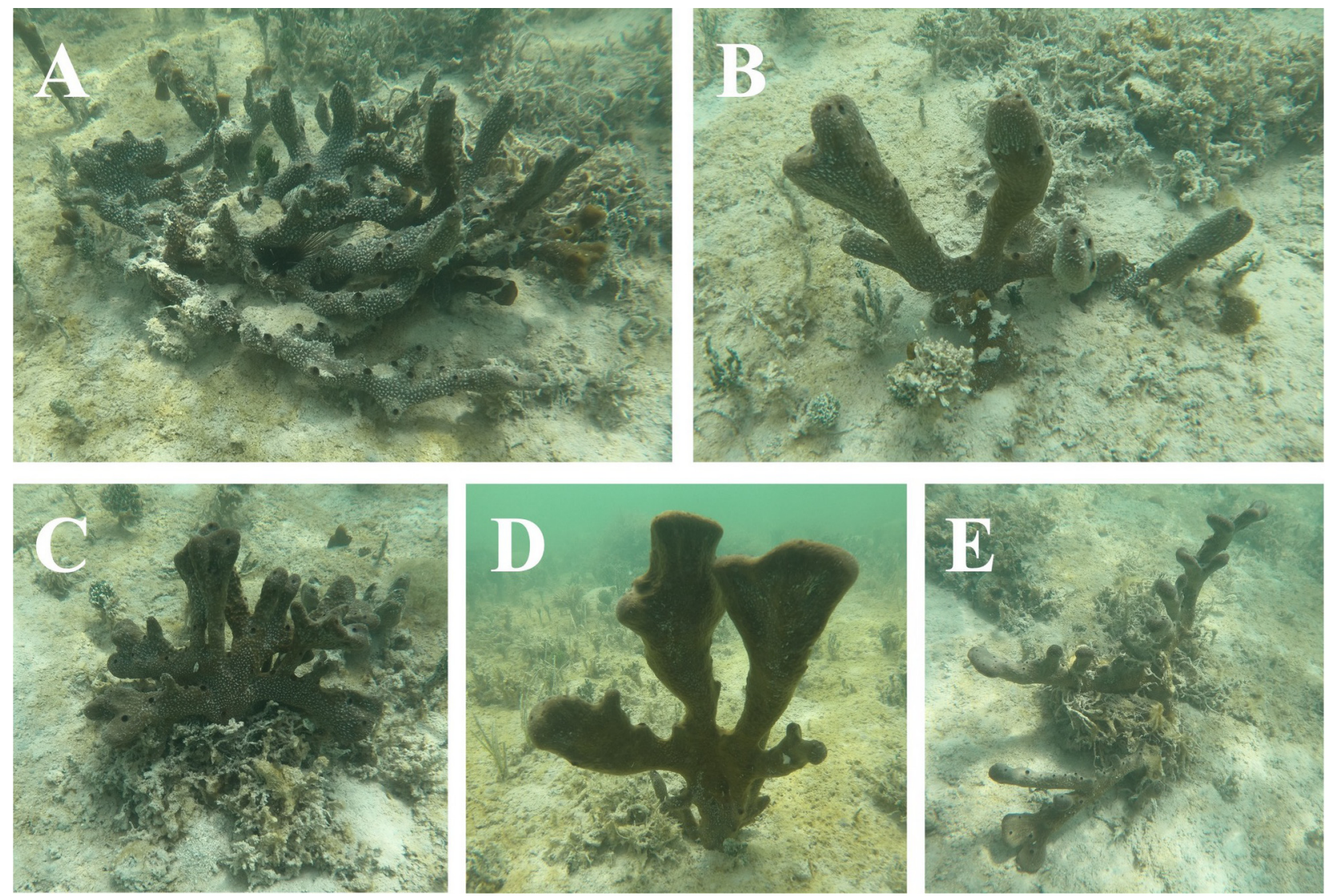

FIGURE 14. Ircinia cf. reteplana (Topsent, 1923). A: USNM 1641984, B: USNM 1641982, C: USNM 1641981, D: USNM 1641985, E: USNM 1641989. 

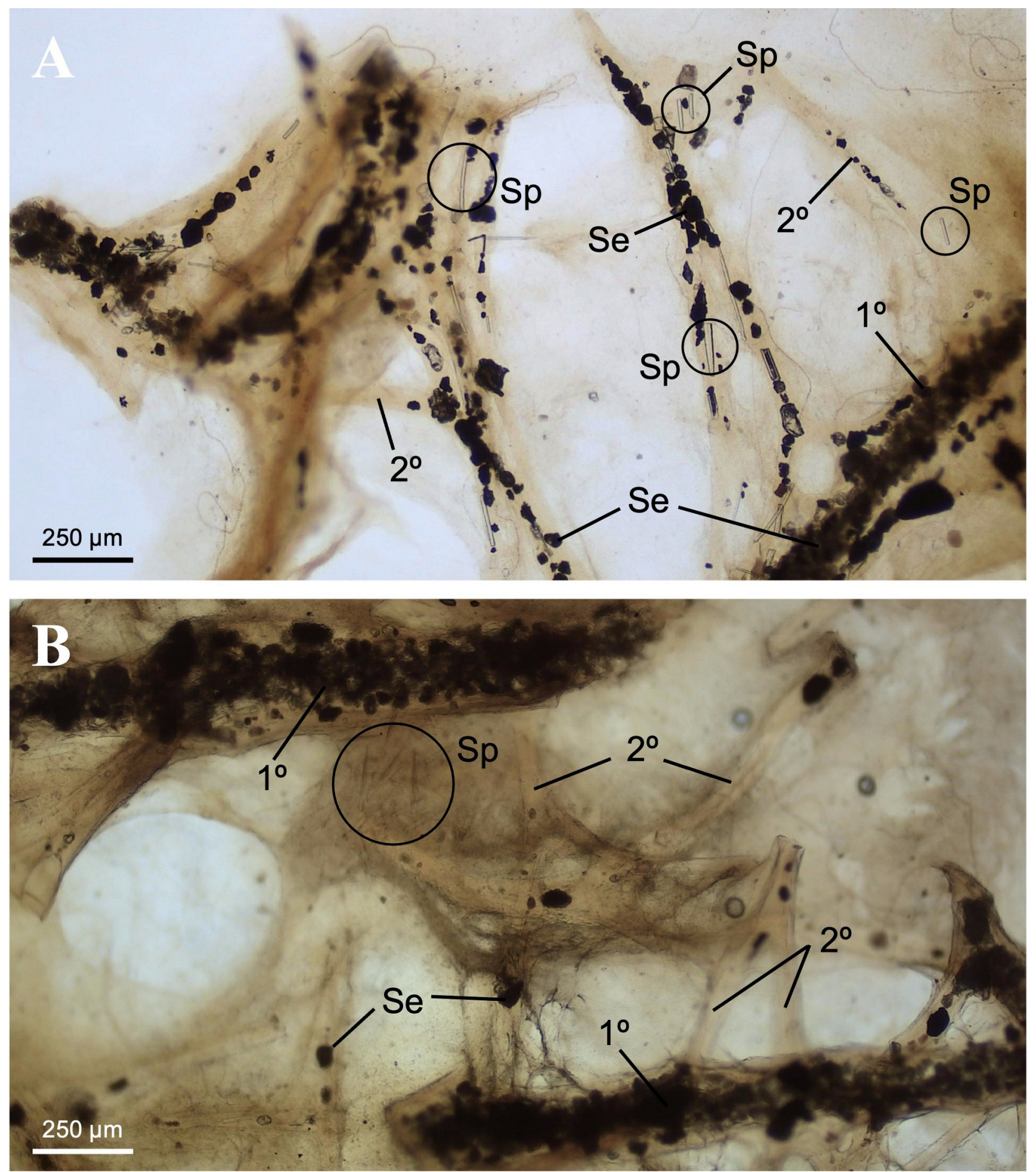

FIGURE 15. Histological sections of Ircinia cf. reteplana USNM 1641982. A: Image showing moderately cored secondary fibers. A primary fiber terminates in a conule on the left of the image. B: Two primary fibers running in parallel, connected by a mesh of secondary fibers. A group of spicules is circled below the topmost primary fiber. Note the difference in the degree of coring of secondary fibers between A and B. Annotations follow Figure 3.

\section{Discussion}

\section{Inclusion within Ircinia}

All Ircinia spp. nov. were difficult to tear when live and produced a sulfurous smell. The Ircinia spp. nov. of the current study all possess cored fascicular primary fibers, albeit lightly cored in I. vansoesti sp. nov., thus separating 
them from Sarcotragus (Hooper \& van Soest 2002). The Ircinia spp. nov. are clearly distinguished morphologically from Psammocinia in that they do not possess an armoring, crustose layer of sediment on the cortex (Hooper \& van Soest 2002), although note that several do contain foreign spicules and sand in the outer dermal layer. However, several of the Ircinia spp. nov. are less clearly distinguished morphologically from Psammocinia in the degree of coring in their secondary fibers; I. bocatorensis sp. nov. and I. cf. reteplana Topsent, 1923 possess cored secondary fibers and three others (I. laeviconulosa sp. nov., I. radix sp. nov., and I. ruetzleri sp. nov.) have lightly to intermittently cored secondary fibers. Among irciniids, cored secondary fibers are thought to only occur in Psammocinia (Hooper $\&$ van Soest 2002). Given that these five species neither form an outgroup nor are monophyletic in the ingroup of the species tree of Kelly et al. (2021), which was inferred using a multi-species coalescent model with genome-wide SNP data, they are unlikely to be Psammocinia mistakenly identified as Ircinia. However, complete phylogenetic resolution of Irciniidae will require an integrative taxonomic study, ideally employing genome-wide SNP data, that encompasses all genera in this family.

\section{Distinctions among the Ircinia spp. nov.}

The Ircinia spp. nov. generally fall into two categories in terms of gross body morphology: those with a massive mound or globular morphology and those with digitate projections. In the first category are I. laeviconulosa sp. nov., I. radix sp. nov., and I. bocatorensis sp. nov. The latter can be readily distinguished from the other two based on two characteristics of the skeletal network: first, the primary fascicular fibers are on average at least twice $(200-520 \mu \mathrm{m})$ the width observed in I. radix sp. nov. $(110-250 \mu \mathrm{m})$ and in I. laeviconulosa sp. nov. $(110-160 \mu \mathrm{m})$ and, second, the interconnecting secondary fibers are cored to a heavier extent in I. bocatorensis sp. nov. (Table 2, Figures 5, 7, 9). Additionally, I. bocatorensis sp. nov. possesses higher conules $(3-5 \mathrm{~mm})$ relative to those of I. laeviconulosa sp. nov. and $I$. radix sp. nov. (less than $2 \mathrm{~mm}$ for both) (Table 2). The other two species, I. radix sp. nov. and $I$. laeviconulosa sp. nov. can be distinguished by the differences in the widths of their primary fibers, with $I$. radix sp. nov. having a larger maximum width $(110-250 \mu \mathrm{m})$ relative to I. laeviconulosa sp. nov. $(110-160 \mu \mathrm{m})$, and a larger degree of coring in its secondary fibers in contrast to those in I. laeviconulosa sp. nov. (Table 2, Figures 7, 9).

In the second category of body growth morphology, those with digitate projections, are $I$. lowi sp. nov., $I$. vansoesti sp. nov., and I. ruetzleri sp. nov. The characteristics that distinguish I. ruetzleri sp. nov. from the other two are the higher degree of coring in its secondary fibers relative to those of $I$. lowi sp. nov. and $I$. vansoesti sp. nov. In the latter two species, coring of secondary fibers is absent or nearly absent. A further sorting character is the larger minimum width of the primary fibers, $120-240 \mu \mathrm{m}$ in I. ruetzleri sp. nov., compared to $90-300 \mu \mathrm{m}$ in $I$. vansoesti sp. nov. and 80-200 $\mu \mathrm{m}$ in $I$. lowi sp. nov. (Table 2, Figures 3, 11, 13). I. lowi sp. nov. can be separated from $I$. vansoesti sp. nov. as it possesses a higher degree of coring by sediment in the primary fibers (whereas coring in $I$. vansoesti sp. nov. is mostly spicule fragments), a more obvious demarcation between secondary and primary fibers, and a smaller maximum width of primary fibers $(80-200 \mu \mathrm{m})$, in contrast to those in I. vansoesti sp. nov. (90-300 $\mu \mathrm{m})$ (Table 2, Figures 3, 11). This summary of morphological characteristics (Table 2) can be used as a multiplefactor guide for taxonomic identification of Caribbean Ircinia.

\section{Phenotypes, Genetics, and Restricted Host Ranges}

The fact that each Ircinia sp. nov. was only found in one habitat type and was restricted to only one or two sites brings to question whether the phenotypes are simply growth forms of much fewer species (i.e. those of I. campana or I. felix) and whether the differences in the microbiomes, which are distinct within each morphospecies (Kelly et al. 2021), are simply the product of localized environmental regimes found at each site and habitat type. The first issue was addressed in Kelly et al. (2021), which evaluated genome-wide SNP data and compared several competing species-grouping models that lumped the morphospecies with I. felix and I. campana to represent the hypothesis that the morphospecies are phenotypes of these two species, and by evaluating support for hypotheses that represented various combinations of lumping growth forms together into a single species based on sympatry, shared habitat types, and morphological similarities. Again, the best-supported hypothesis of Kelly et al (2021) modeled each morphospecies as a genetically distinct species.

Multispecies-coalescent analyses, which include BFD*, have been criticized for over-splitting populations into individual species (Sukumaran \& Knowles 2017). The authors of Kelly et al. (2021) encountered a similar pattern in that the best-supported hypothesis split two geographically distant I. strobilina populations (one from Belize and the other from Panama) into two different (though sister) species. Since sponges generally produce larvae that settle within hours to days (Maldonado \& Riesgo 2008), the authors interpreted this as a benchmark for population- 
level genetic differentiation and cautioned against splitting this species without further evidence. However, the hypothesis that received the highest support from BFD* also split the Floridian and Panamanian I. campana into two distinct species that fell into different clades that were separated by the maximum genetic distance on the tree. This finding of high genetic structure between the same two populations in Kelly et al. (2021) has been corroborated independently by another study that suggested cryptic speciation might be present within the nominal species $I$. campana (Griffiths et al. 2021). Given the similarities in the genetic results between the two studies, we advocate for further investigations into the possibility of splitting I. campana into multiple species.

Kelly et al. (2021) discovered that the Ircinia spp. nov. each possess compositionally unique and conserved microbiomes, a trend that held for the other Caribbean Ircinia species I. felix, I. strobilina, and I. campana (although with population-level differences), and that dissimilarities in microbiome compositions also scaled significantly with host genetic distances. Thus, two questions stand: first, is the environment or host identity a stronger force in shaping microbiome compositions and, second, can the microbiome composition be used as a taxonomic character? Based on the compositional distinctiveness of the microbiomes among Caribbean Ircinia, including those that share the same physical habitat, and the compositional differences between Ircinia microbiomes and the microbial communities of the surrounding seawater (Kelly et al. 2021), it is reasonable to postulate that the hosts are exerting some control over their microbiomes. Additionally, microbiome compositions of other Ircinia species are stable despite fluctuations in temperature and irradiance (Erwin et al. 2012) and salinity (Glasl et al. 2018). Despite these data, we do not have any direct evidence of whether Caribbean Ircinia can alter their microbiomes to better exploit the resources found in each environment, or whether they preferentially settle in locations that would best suit the specific microbiome composition that they have evolved to maintain. However, given that multiple studies have now found that microbiome dissimilarity scales positively with genetic distance at the level of the population (Griffiths et al. 2019, Easson et al. 2020), among congeneric species (Kelly et al. 2021), and among more distantly related species (Schöttner et al. 2013, Easson \& Thacker 2014, Thomas et al. 2016), their use as taxonomic characters in the future remains a possibility. In order to disentangle the effects of environment and host genotype, and consequently identify if any aspects of the microbiome could be used as taxonomic identifiers of the hosts, reciprocal transplant experiments and long-term monitoring of Caribbean Ircinia microbiomes should be performed.

\section{Additional Notes on the Use of Phenotype in Irciniid Taxonomy and Outlook}

The three Ircinia spp. nov. in the second (branching) morphology category appear more morphologically similar than the three Ircinia spp. nov. in the massive mound or globular morphology category and might be difficult to distinguish in the field. These similarities hold in the overall impressions that the gross morphologies of the sponges give and in the overlap among the dimensions of their finer-scale characteristics (e.g. oscula diameters and fiber widths). However, none of the three Ircinia spp. nov. in the branching category are the next closest relatives to each other; in fact, each is included in one of the three major clades of the species tree of Kelly et al. (2021). Additionally, the genetic distances reported by Kelly et al. (2021) between I. vansoesti sp. nov. (as 'Sp. 1') and either I. ruetzleri sp. nov. (as 'Sp. 2') or I. lowi sp. nov. (as 'Encrusting') is the maximum genetic distance on the tree which, for reference, also includes two populations of each I. strobilina and I. campana, and one population of I. felix. Likewise, the genetic distance between I. lowi sp. nov. and I. ruetzleri sp. nov. is the second greatest on the tree. For additional context, I. felix appeared more closely related to I. strobilina than any of these three Ircinia spp. nov. are to each other. Thus, the use morphological dissimilarity in Ircinia is not a stand-alone indicator of species boundaries. As discussed above, the splitting of I. campana into multiple, genetically distinct species could be a further demonstration of this principle.

Phenotypic variability and the resultant difficulties that it presents to identifying boundaries among genera and species of irciniids is an obvious issue that must be resolved in the future. One problematic taxonomic character that can be addressed on the basis of the current study is the use of the absence of secondary primer coring as a diagnostic feature for Ircinia (Hooper \& van Soest 2002). This assertion is corroborated by the results of Sandes \& Pinheiro (2014), who also described Ircinia with coring of secondary fibers. To further resolve the appropriateness of morphological characters for use in irciniid taxonomy, we advocate for an expansion of integrative taxonomic approaches that include genome-wide and phenotypic data to delimit species boundaries, which could help guide the identification of morphological traits that set apart species and genera.

Understanding sponge biodiversity is imperative to the protection of tropical marine habitats given the multitude of core ecological functions sponges perform (Diaz \& Rützler 2001, Wulff 2001, Bell 2008). Ircinia are among 


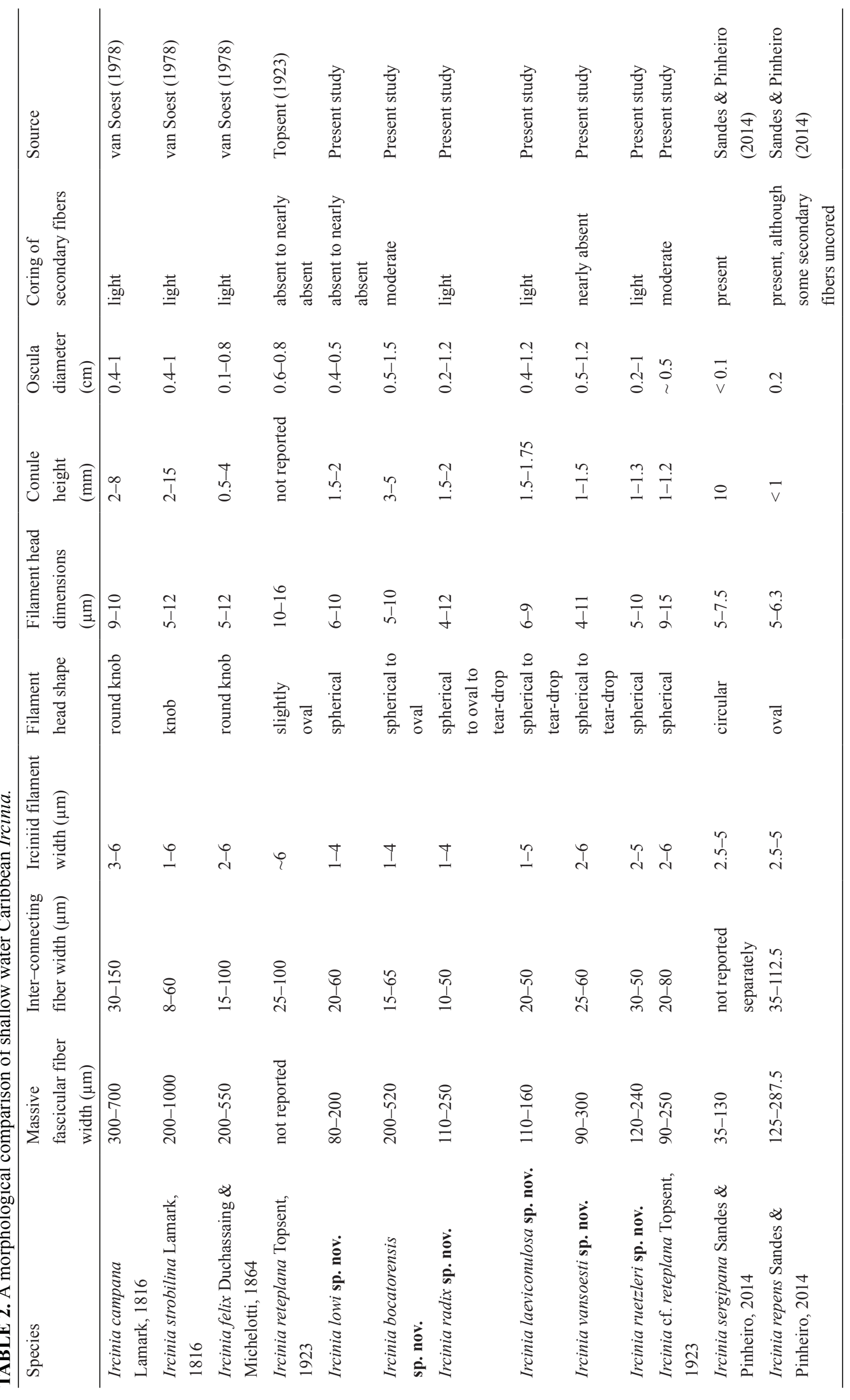


the most abundant and ecologically influential sponges on Caribbean reefs although they are also, unfortunately, among the most susceptible to environmental perturbations (Wulff 2006, 2013). Here, we have demonstrated that disentangling species boundaries within Ircinia, arguably one of the most taxonomically challenging sponge genera, can be accomplished with high confidence using an integrative taxonomic framework that evaluates morphology, microbiome composition, and genome-wide SNP data (Kelly et al. 2021). The adoption of these data criteria in future species delimitation studies could help further describe species richness within this ecologically important genus and ultimately help science document and defend the hidden biodiversity in sponge fauna.

\section{Acknowledgements}

We thank Dr. Jackie L. Collier and Dr. Liliana Dávalos-Alvarez for their comments on the manuscript; the staffs of the Smithsonian Tropical Research Institute's Bocas Research Station, the Smithsonian's Carrie Bow Cay Field Station, and the Mote Marine Laboratory and Aquarium's Elizabeth Moore International Center for Coral Reef Research \& Restoration for their support on logistical aspects of the field work and for helping to organize collection permits. We thank the Ministry of the Environment of Panama; the National Oceanic and Atmospheric Administration's Office of National Marine Sanctuaries; the Florida Fish and Wildlife Conservation Commission; and the Belize Fisheries Department's Ministry of Agriculture, Fisheries, Forestry, the Environment \& Sustainable Development for granting scientific research permits. We would like to thank Barrett Brooks and Dr. Karen Koltes for help with specimen collections in Carrie Bow Cay. This study was supported by a Fellowship of Graduate Student Travel (Society for Integrative and Comparative Biology) and Dr. David F. Ludwig Memorial Student Travel Scholarship (Association for Environmental Health and Sciences Foundation) awarded to J.B.K. and by grants awarded to R.W.T. from the U.S. National Science Foundation (DEB-1622398, DEB-1623837, OCE-1756249, EF-2025121).

\section{References}

Archer, S.K., Stevens, J.L., Rossi, R.E., Matterson, K.O. \& Layman, C.A. (2017) Abiotic conditions drive significant variability in nutrient processing by a common Caribbean sponge, Ircinia felix. Limnology and Oceanography, 62, $1783-1793$. https://doi.org/10.1002/lno.10533

Bell, J.J. (2008) The functional roles of marine sponges. Estuarine, Coastal and Shelf Science, 79, 341-353. https://doi.org/10.1016/j.ecss.2008.05.002

Cook, S. de C. \& Bergquist, P.R. (1999) New species of dictyoceratid sponges from New Zealand: Genus Ircinia (Porifera: Demospongiae: Dictyoceratida). New Zealand Journal of Marine and Freshwater Research, 33, 545-563. https://doi.org/10.1080/00288330.1999.9516899

Degnan, J.H. \& Rosenberg, N.A. (2006) Discordance of species trees with their most likely gene trees. PLOS Genetics, 2 , e68. https://doi.org/10.1371/journal.pgen.0020068

Diaz, M.C. \& Rützler, K. (2001) Sponges: an essential component of Caribbean coral reefs. Bulletin of Science Marine, 69 , $535-546$.

Diaz, M.C. (2005) Common sponges from shallow marine habitats from Bocas del Toro Region, Panama. Caribbean Journal of Science, 41, 465-475.

Easson, C.G., Chaves-Fonnegra, A., Thacker, R.W. \& Lopez, J. V (2020) Host population genetics and biogeography structure the microbiome of the sponge Cliona delitrix. Ecology and Evolution, 10, 2007-2020. https://doi.org/10.1002/ece3.6033

Easson, C.G. \& Thacker, R.W. (2014) Phylogenetic signal in the community structure of host-specific microbiomes of tropical marine sponges. Frontiers in Microbiology, 5, 532. https://doi.org/10.3389/fmicb.2014.00532

Erpenbeck, D., Galitz, A., Ekins, M., Cook, S. de C., van Soest, R.W.M., Hooper, J.N.A. \& Wörheide, G. (2020) Soft sponges with tricky tree: On the phylogeny of dictyoceratid sponges. Journal of Zoological Systematics and Evolutionary Research, $58,27-40$. https://doi.org/10.1111/jzs.12351

Erwin, P.M., Pita, L., López-Legentil, S. \& Turon, X. (2012) Stability of sponge-associated bacteria over large seasonal shifts in temperature and irradiance. Applied and Environmental Microbiology, 78, 7358-7368. https://doi.org/10.1128/AEM.02035-12

Erwin, P.M. \& Thacker, R.W. (2007) Incidence and identity of photosynthetic symbionts in Caribbean coral reef sponge assemblages. Journal of the Marine Biological Association of the United Kingdom, 87, 1683-1692. https://doi.org/10.1017/S0025315407058213 
Glasl, B., Smith, C.E., Bourne, D.G. \& Webster, N.S. (2018) Exploring the diversity-stability paradigm using sponge microbial communities. Scientific Reports, 8, 8425 .

https://doi.org/10.1038/s41598-018-26641-9

Griffiths, S.M., Antwis, R.E., Lenzi, L., Lucaci, A., Behringer, D.C., Butler, M.J. \& Preziosi, R.F. (2019) Host genetics and geography influence microbiome composition in the sponge Ircinia campana. Journal of Animal Ecology, 88, 16841695. https://doi.org/10.1111/1365-2656.13065

Griffiths, S.M., Butler, M.J., Behringer, D.C., Pérez, T. \& Preziosi, R.F. (2021) Oceanographic features and limited dispersal shape the population genetic structure of the vase sponge Ircinia campana in the Greater Caribbean. Heredity, $126,63-76$. https://doi.org/10.1038/s41437-020-0344-6

Hooper, J. \& van Soest, R.W.M. (Eds.) (2002) Systema Porifera: A guide to the classification of sponges. Kluwer Academic/ Plenum Publishers, New York, Boston, Dordrecht, London and Moscow, xlviii + 1708 pp. https://doi.org/10.1007/978-1-4615-0747-5

Kelly, J.B., Carlson, D.E., Low, J.S., Rice, T. \& Thacker, R.W. (2021) The relationship between microbiomes and selective regimes in the sponge genus Ircinia. Frontiers in Microbiology, 12, 489. https://doi.org/10.3389/fmicb.2021.607289

Kelly, J.B. \& Thacker, R.W. (2020) Microbiomes and host genetics provide evidence for ecological diversification among Caribbean members of the sponge genus Ircinia; Nardo, 1833. bioRxiv, 2020.09.04.282673. https://doi.org/10.1101/2020.09.04.282673

Leaché, A.D., Fujita, M.K., Minin, V.N. \& Bouckaert, R.R. (2014) Species delimitation using genome-wide SNP Data. Systematic Biology, 63, 534-542. https://doi.org/10.1093/sysbio/syu018

Maldonado, M. \& Riesgo, A. (2008) Reproduction in the phylum Porifera: A synoptic overview. Treballs de la Societat Catalana de Biologia, 59, 29-49.

Rützler, K., Diaz, M.C., van Soest, R.W.M., Zea, S., Smith, K.P., Alvarez, B. \& Wulff, J. (2000) Diversity of sponge fauna in mangrove ponds, Pelican Cays, Belize. Atoll Research Bulletin, 476, 229-248. https://doi.org/10.5479/si.00775630.467.229

Sandes, J. \& Pinheiro, U.S. (2014) Dictyoceratida (Porifera: Demospongiae) from tropical southwestern Atlantic (northeastern Brazil, Sergipe State) and the description of three new species. Zootaxa, 3838 (4), 445-461. https://doi.org/10.11646/zootaxa.3838.4.4

Schöttner, S., Hoffmann, F., Cárdenas, P., Rapp, H.T., Boetius, A. \& Ramette, A. (2013) Relationships between host phylogeny, host type and bacterial community diversity in cold-water coral reef sponges. PLOS ONE, 8, e55505. https://doi.org/10.1371/journal.pone.0055505

van Soest, R.W.M. (1978) Marine sponges from Curaçao and other Caribbean localities. Part I. Keratosa. In: Hummelinck, P.W. \& Van der Steen, L.J. (Eds.), Uitgaven van de Natuurwetenschappelijke Studiekring voor Suriname en de Nederlandse Antillen. No. 94. Studies on the Fauna of Curaçao and other Caribbean Islands, 56 (179), pp. 1-94. http://www.repository. naturalis.nl/document/549917.

van Soest, R.W.M., Boury-Esnault, N., Hooper, J.N.A., Rützler, K., de Voogd, N.J., Alvarez, B., Hajdu, E., Pisera, A.B., Manconi, R., Schönberg, C., Klautau, M., Kelly, M., Vacelet, J., Dohrmann, M., Díaz, M.-C., Cárdenas, P., Carballo, J.L., Ríos, P., Downey, R. \& Morrow, C.C. (2021) World Porifera Database. Available from: http://www.marinespecies.org/porifera (accessed 1 March 2021)

Sukumaran, J. \& Knowles, L.L. (2017) Multispecies coalescent delimits structure, not species. Proceedings of the National Academy of Sciences, 114, 1607-1612. https://doi.org/10.1073/pnas.1607921114

Thomas, T., Moitinho-Silva, L., Lurgi, M., Björk, J.R., Easson, C., Astudillo-García, C., Olson, J.B., Erwin, P.M., LópezLegentil, S., Luter, H., Chaves-Fonnegra, A., Costa, R., Schupp, P.J., Steindler, L., Erpenbeck, D., Gilbert, J., Knight, R., Ackermann, G., Victor Lopez, J., Taylor, M.W., Thacker, R.W., Montoya, J.M., Hentschel, U. \& Webster, N.S. (2016) Diversity, structure and convergent evolution of the global sponge microbiome. Nature Communications, 7, 11870. https://doi.org/10.1038/ncomms 11870

Wilkinson, C.R. \& Cheshire, A.C. (1990) Comparisons of sponge populations across the Barrier Reefs of Australia and Belize: evidence for higher productivity in the Caribbean. Marine Ecology Progress Series, 67, 285-294. https://doi.org/10.3354/meps067285

Wulff, J. (1994) Sponge feeding by Caribbean angelfishes, trunkfishes, and filefishes. In: van Soest, R.W.M., van Kempen, T.M.G. \& Braekman, J.C. (Eds.), Sponges in Time and Space. Biology, Chemistry, Paleontology. Balkema, Rotterdam, pp. $265-271$.

Wulff, J. (2001) Assessing and monitoring coral reef sponges: why and how? Bulletin of Marine Science, 69, 831-846.

Wulff, J. (2006) Rapid diversity and abundance decline in a Caribbean coral reef sponge community. Biological Conservation, $127,167-176$. https://doi.org/https://doi.org/10.1016/j.biocon.2005.08.007

Wulff, J. (2013) Recovery of sponges after extreme mortality events: morphological and taxonomic patterns in regeneration versus recruitment. Integrative and Comparative Biology, 53, 512-523.

https://doi.org/10.1093/icb/ict059 